\title{
MODELOS ROMANOS EN LA ARQUITECTURA MONUMENTAL DE COLONIA PATRICIA CORDUBA
}

\author{
POR
}

\author{
CARLOS MÁRQUEZ ${ }^{1}$ \\ Universidad de Córdoba
}

\begin{abstract}
RESUMEN
Este trabajo analiza de forma detallada algunos elementos arquitectónicos romanos de Colonia Patricia para poder adscribirlos a edificios urbanos. De esta forma se pueden plantear nuevas hipótesis sobre cronología, función e inserción de los mismos en el marco urbanístico, concluyendo la absoluta dependencia de la capital de la provincia Baetica de modelos procedentes de Roma a los que copia en material y dimensiones.
\end{abstract}

\section{SUMMARY}

Examination of a number of Roman architectural fragments from Colonia Patricia makes possible the identification of the buildings to which they belong. This prompts a revision not only of the date and function of these buildings, but also of their placement within the urban landscape. In the choice of materials and scale of its buildings Patricia closely follows models from Rome itself.

El estudio de la decoración arquitectónica ha sido decisivo para pergeñar por primera vez la imagen de Córdoba romana desde el tardío periodo republicano hasta el bajo-imperial. En las próximas páginas pretendo demostrar la validez de un método que analice todos los elementos conservados de la decoración arquitectónica romana como premisa para obtener conclusiones cronológicas, tipológicas $\mathrm{y}$ funcionales de algunos edificios cordobeses de carácter público y privado ${ }^{2}$.

El análisis estilístico se complementa con el que ahora se emprende mediante el estudio de otras categorías implícitas en las piezas cordobesas, tales como las dimensiones y procedencia de los frag-

${ }^{1}$ Este trabajo forma parte de una investigación desarrollada bajo la dirección del Prof. H. von Hesberg en el Instituto de Arqueología de la Universidad de Colonia gracias a una beca de la Fundación Alexander von Humboldt, entidades y persona a quienes agradezco su mecenazgo y ayuda.

2 Un magistral trabajo de Hesberg da las claves principales para su comprensión en el ámbito urbano. Vid. H. von Hesberg, «La decorazione architettonica di Cordova. Sulla funzione dell'ornamentazione architettonica in una città romana» en P. León (ed.), Colonia Patricia Corduba: una reflexión arqueológica, Córdoba 1996, 156 ss. mentos. En lo que a las medidas se refiere, se trata de restituir las dimensiones aproximadas de algunas piezas emblemáticas a partir de los fragmentos conservados mediante la aplicación de diversos módulos (explicitados en cada caso). No es de otra forma como se puede intuir la apariencia de las construcciones habida cuenta de la inexistencia de edificios romanos conservados hasta nuestros días.

La procedencia del material es un dato muy importante para aproximarse a la configuración monumental de la Colonia Patricia. A pesar del pequeño porcentaje de piezas con origen conocido, podemos constatar varios focos en los que se detecta una mayor concentración y una mayor cantidad y cualidad de piezas (foro y teatro), si bien no estamos en condiciones de concretar ni la función ni la imagen de todos los edificios que los componen. Afortunadamente la concentración de fragmentos en unas determinadas zonas permite localizar nuevos conjuntos monumentales (como el de la calle Morería) de los que hasta ahora apenas se tenía noticias. La morfología de determinados elementos arquitectónicos permite constatar la existencia de pórticos, arcos honoríficos, puertas urbanas y una variada tipología de monumentos funerarios; de alguno de ellos conocemos su ubicación pero de otros se planteará un origen probable, atendiendo a su función y relación con los conjuntos y edificios antes mencionados.

El estudio del material de decoración arquitectónica ha permitido distinguir con toda certeza una serie de edificios que paso a exponer, mientras que otros quedan a nivel de hipótesis.

\section{El Foro Colonial ${ }^{3}$ (Figura $1, \mathrm{n}^{\circ} 1$ )}

El conocimiento que hoy se tiene de este complejo permite matizar la tradicional ubicación y ex-

${ }^{3}$ El mayor número de piezas procede de las excavaciones de la calle Cruz Conde, traídas en época tardorromana o medieval de diversas procedencias de la ciudad. 

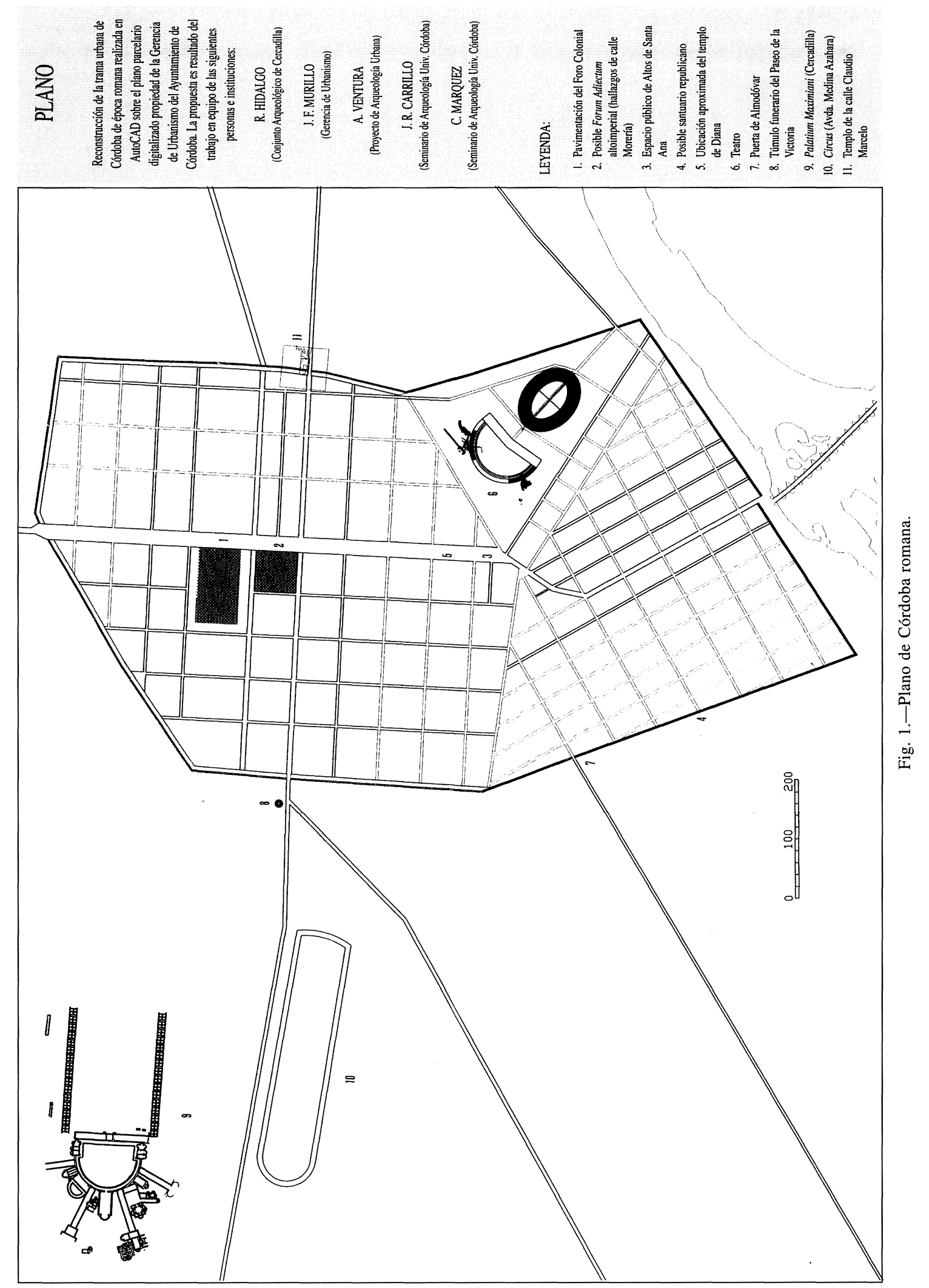
tensión del mismo ${ }^{4}$ y confirma la alargada forma de la plaza. No cabe duda acerca de la antigüedad de este foro que con seguridad fue el primero que se construyó en la ciudad. Sobre el mismo en época republicana no existen más que noticias literarias que señalan también su total destrucción en época de las Guerras Civiles. Ahora bien, se nos va a permitir trazar una hipótesis acerca de la extensión del foro de la Córdoba fundacional. De origen republicano es el tipo de foro con pórticos en forma de [, que rodean una plaza en cuyo interior se ubica el templo. Este pórtico se ve separado a través del cardo maximus de la plaza antistante donde se colocan otros edificios: este «hipotético» modelo puede aplicarse muy bien al caso de Córdoba cuando se observa que el cardo máximo bordea el lado este de la plaza enlosada dejando al otro lado de la misma una plaza que todavía se conserva en la trama urbana actual con un templo en su centro: se trata de la plaza e iglesia de S. Miguel, cuya orientación actual no va en eje con la de la plaza forense si bien algunos muros romanos excavados sí la tendrían ${ }^{5}$. En época augustea esta plaza tuvo probablemente una ampliación y en ella tuvieron cabida algunos de los siguientes edificios:

1.1. Templos augusteos: ya para época augustea hemos de constatar la reconstrucción del complejo forense al observar los fragmentos de ménsulas en piedra caliza (fig. 2) de $18 \mathrm{~cm}$. de altura que allí se localizan y que demuestran la grandiosidad del edificio, con toda seguridad, un templo. Contamos además con una pilastra augustea (fig. 3) que podría formar la esquina de un altar monumental similar al Ara Pacis y, finalmente, a otro edificio de culto pertenecería el fragmento de una consola parótida datable en el primer periodo imperial (fig 4) ${ }^{6}$.

1.2. Pórticos: a un primer momento imperial remiten también los capiteles corintizantes de pilastra (fig. 5), que nos indican la presencia de pórticos en el recinto forense y que adornarían sus muros interiores. Otro pórtico del foro o de sus inmediatos

4 A. Marcos, A. M. Vicent, «Investigación, técnicas y problemas de las excavaciones en solares de la ciudad de Córdoba y algunos resultados topográficos generales» en Arqueología de las ciudades modernas superpuestas a las antiguas, Zaragoza 1985, 248; A. Ibáñez, R. Secilla, J. Costa, «Novedades de arqueología urbana en Córdoba» en P. León (ed.), Colonia Patricia Corduba: una reflexión arqueológica, Córdoba 1996, 119 ss; L. Aparicio, A. Ventura, «Flamen provincial documentado en Córdoba y nuevos datos sobre el Foro de la Colonia Patricia», Anales de Arqueología Cordobesa 7, 1996, 251 ss.

5 A. Ibáñez et alii, cit. (n. 4), 126, fig. 4.

${ }^{6}$ Hesberg, cit. (n. 2) , 164, fig. 25 a-b. Aunque Hesberg lo cataloga como capitel jónico, ya plantea en la nota 76 su insólita decoración.

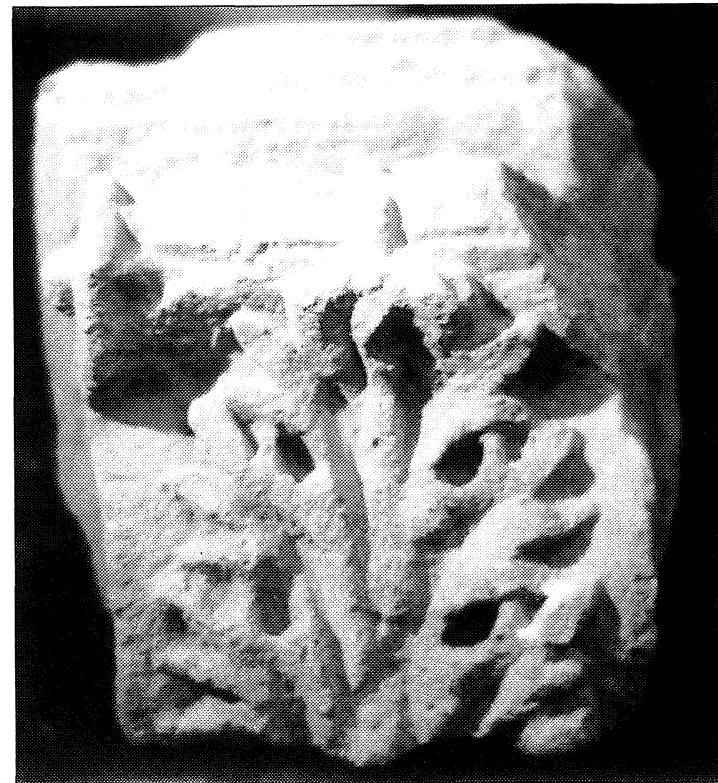

Fig. 2.-Ménsula con hoja de acanto del Foro Colonial.

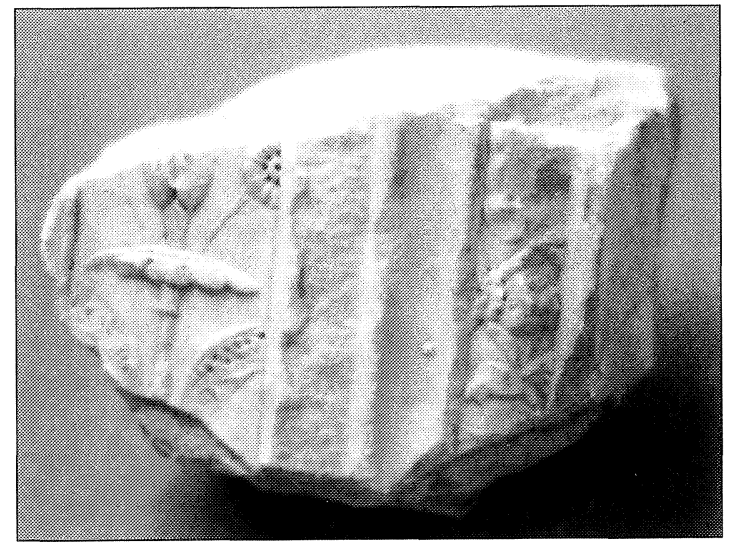

Fig. 3.-Pilastra decorada con motivos vegetales y cabezas de animales.

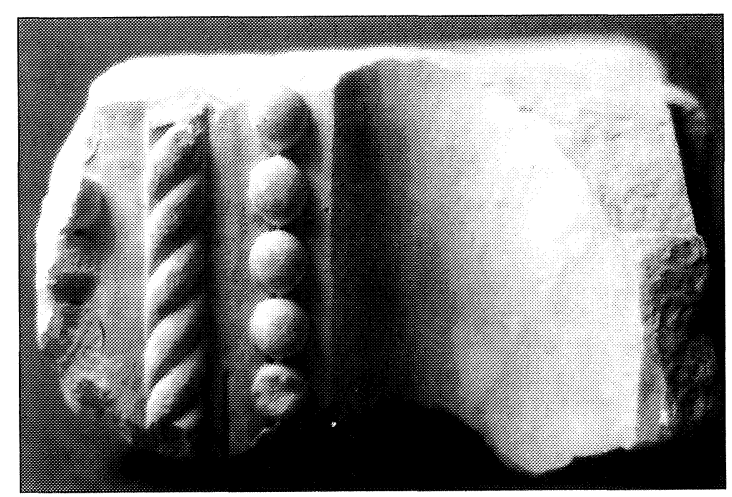

Fig. 4.-Ménsula parótida del Foro Colonial. 


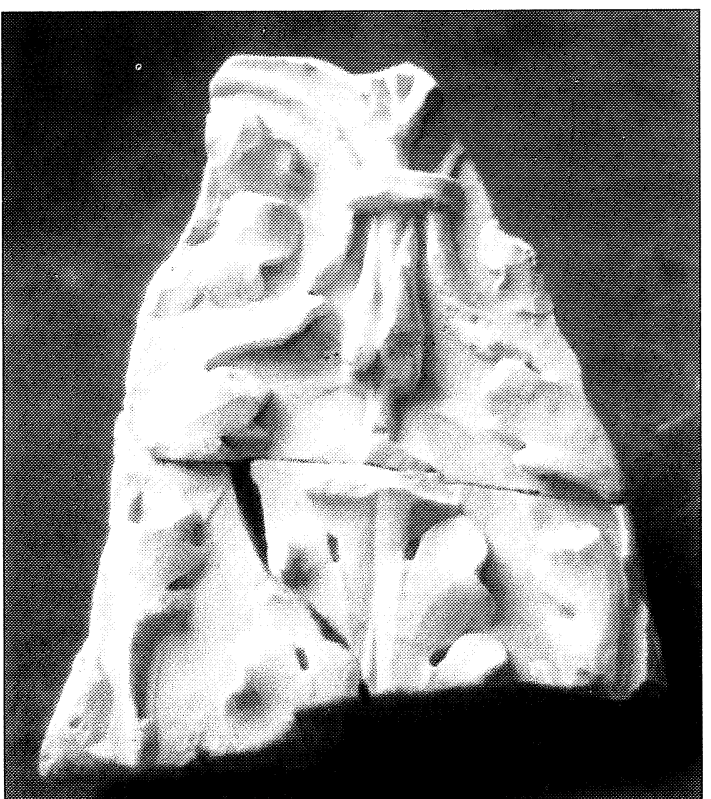

Fig. 5.-Capitel de pilastra del Foro Colonial.

alrededores es el que se vería adornado con las basas aparecidas en la calle B. Laportilla (fig. 6), cuya morfología y motivos ornamentales ${ }^{7}$ pueden ser fechados a comienzos de época imperial ${ }^{8}$ en atención a las siguientes razones:

- En primer lugar porque es sencillamente inconcebible en el ámbito público — al que estas basas pertenecerían - su realización en piedra local en ese periodo. Entraría dentro de la lógica en una ciudad en la que se conservase gran cantidad de elementos ornamentales en piedras locales, lo que no es el caso de Colonia Patricia donde la presencia del mármol anula en su práctica totalidad la de otros materiales.

- En segundo lugar, la construcción del templo de la calle de Claudio Marcelo ${ }^{9}$, fechado entre el periodo julio-claudio y el flavio, se inscribe dentro de este mismo ámbito oficial. Sus basas, todas en mármol, tienen una morfología distinta a las ahora analizadas, quedando constancia de esa forma que no pueden pertenecer a un mismo momento. Las del templo serían posteriores.

7 Véase un análisis detallado de las mismas en C. Márquez, «Corrientes y materiales en la arquitectura de la Córdoba romana», Anales de Arqueología Cordobesa 6, 1995, $85 \mathrm{ss}$.

8 Sobre el motivo en punta de lanza adornando el imoscapo del fuste, una reciente opinión en contra de la cronología augustea es la de Torsten Mattern, «Segmentstab-Kanneluren. Zur Entwicklung und Verbreitung eines Bauornamentes», Boreas 18, 1995, 57 ss.

9 J. L. Jiménez, «El templo romano de la calle Claudio Marcelo en Córdoba: aspectos cronológicos y funcionales» en P. León (ed.), Colonia Patricia Corduba: una reflexión arqueológica, Córdoba 1996, 129 ss.

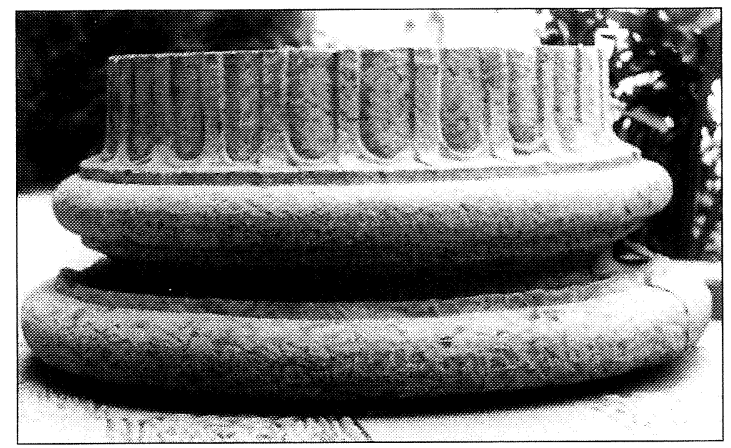

Fig. 6.-Basas de pórtico en el Foro Colonial.

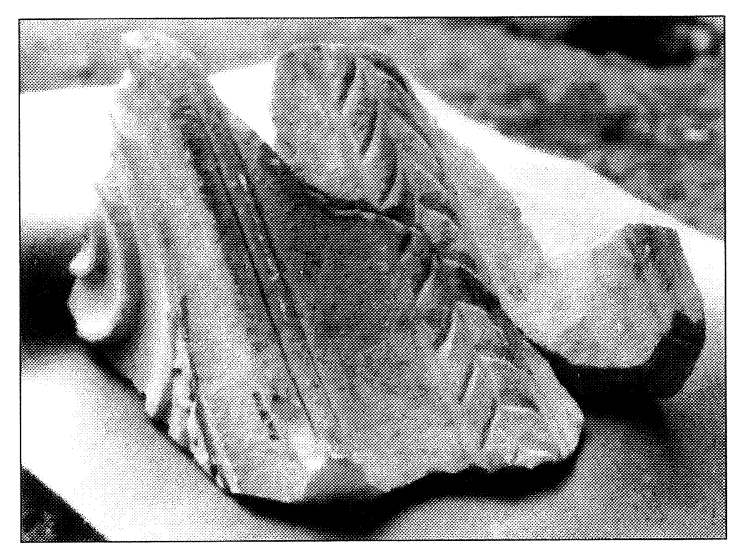

Fig. 7.-Clave de arco honorífico.

1.3. Arcos de triunfo: también en el foro o en sus proximidades se alzarían algunos arcos de triunfo que actúan a modo de señales monumentales; además del arco con clave de Victoria encontrado en la calle Osario ${ }^{10}$ contamos con, al menos, otro monumento de similar función honorífica, conocido a través de una clave de arco (fig. 7). La importancia que reviste el hecho de encontrar estos dos testimonios en el lado Este del foro, viene dada por la relación existente entre los arcos y los principales templos de la ciudad; así el Capitolio de Pompeya se ve flanqueado en época imperial por dos arcos laterales y por un tercero algo más retranqueado; no hay ningún otro arco honorífico en este foro; algo similar ocurre en el foro de Augusto, en Roma y, tal como afirma S. de Maria, «con l'età giulio-claudia archi esplicitamente onorari compaiono ripetutamente a fianco dell'edificio templare prospettante il foro di municipi e colonie, secondo lo schema urbano presente nella sistemazione augustea del Foro ro-

${ }^{10}$ A. Marcos, «Ménsula con clave decorada de un posible arco triunfal de Córdoba romana», Corduba Archaeologica $13,1982-82,45$ ss. 


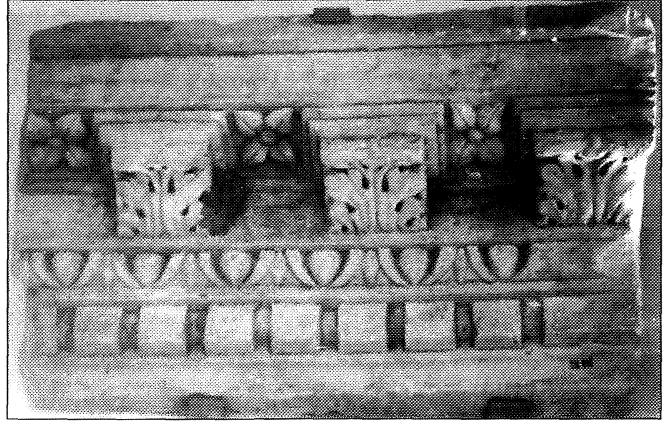

Fig. 8.-Cornisa semicircular.

mano e applicato anche nel foro di Augusto» ${ }^{11}$. Se trata, por tanto, de una situación que parece encontrar refrendo en Colonia Patricia; sería esta misma zona oriental la que albergase los edificios religiosos emblemáticos del foro.

1.4. Edificios absidados (¿Basílica?): el límite de la plaza forense se ve rica y variadamente decorado con una diversa cantidad de elementos, entre los que predominan las cornisas, siempre de mármol. De entre ellas destacan unas cornisas circulares (fig. 8) halladas en la esquina NE del foro, cornisas que adornarían el interior de una exedra o de un edificio absidado; precisamente esta última característica tenía un monumento excavado en esta zona y que ha sido vinculado con la basílica forense $^{12}$; conscientes de la posible adscripción a este edificio no se pueden descartar otras funciones, por ejemplo de tipo cultual-dinástico.

1.5. Alrededores del foro: de difícil adscripción a un tipo concreto de edificio es la pieza de la fig. 9, lastra relivaria de un tipo similar al que se observa en relieves históricos flavio-trajaneos ${ }^{13} \mathrm{y}$ también un edificio oficial situado en la actual avenida del Gran Capitán, al que pertenece la pieza de la fig. 10, edificio al que no podemos, por el momento, dar una finalidad concreta.

\section{Forum Adiectum (Figura 1, n ${ }^{\circ}$ 2).}

Como dijimos anteriormente, en este ámbito de la ciudad romana destaca la calle Morería por el cúmulo de material allí recuperado. Su análisis cua-

\footnotetext{
"EAA $2^{\circ}$ Supp. I, 360, voz Arco.

12 Marcos-Vicent, cit. (n. 4), 248.

13 Véase su paralelo en Roma coronando Ios Anaglypha Traiani en M. Torelli, Tipology and Structure of Roman Historical Reliefs, Ann Arbor 1982, 89 ss.
}

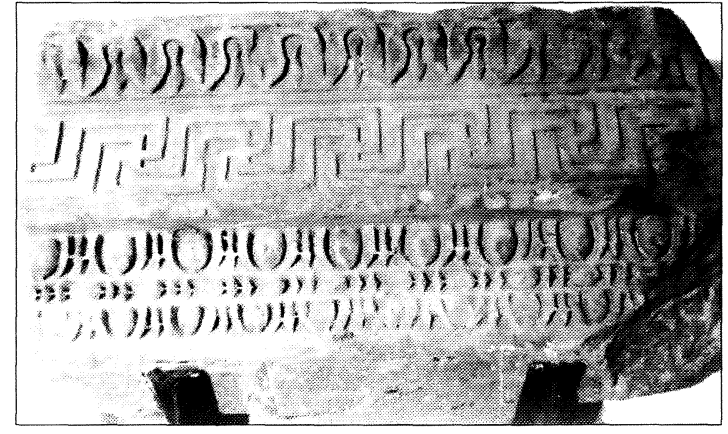

Fig. 9.-Lastra relivaria.

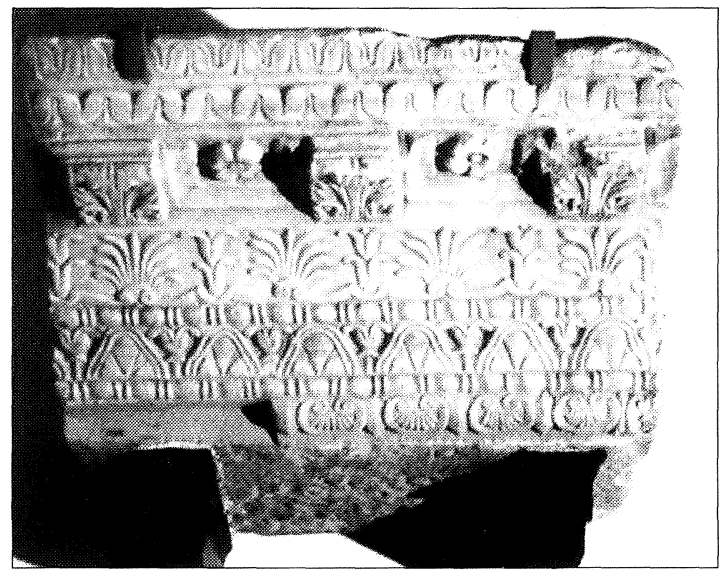

Fig. 10.-Cornisa.

litativo confirma la importancia de la zona tal como intentaremos demostrar a continuación.

2.1. Pórtico del Forum Adiectum: la presencia de un pórtico en este complejo queda confirmado por dos fragmentos de fuste con contracanales ${ }^{14} \mathrm{cu}$ yas medidas avalan sin lugar a dudas (su diámetro es de $80 \mathrm{~cm}$ aprox.) su utilización en un pórtico. El interior del mismo se adornaría con nichos coronados con cornisitas curvas y adinteladas (figs. $11 \mathrm{y}$ 12) cuya apariencia hace suponer que pudieran albergar estatuas de summi viri a imagen del Forum Augustum en Roma ${ }^{15}$. No podemos olvidar la aparición en el subsuelo de la calle Morería de la estatua loricata de la colección Tienda ${ }^{16}$.

${ }^{14}$ Márquez, cit. (n. 7), 86 donde se vincula este tipo de fustes con los pórticos.

15 P. Zanker, Forum Augustum, Tübingen 1968. Lo mismo ha demostrado Barrera en Mérida; vid. J. L. de la Barrera, $L a$ decoración arquitectónica de los foros de Mérida (en prensa).

16 D. Vaquerizo (coord.), Catálogo de la Exposición Córdoba en tiempos de Séneca, Córdoba 1996, 34 ss. (con bibliografía). 


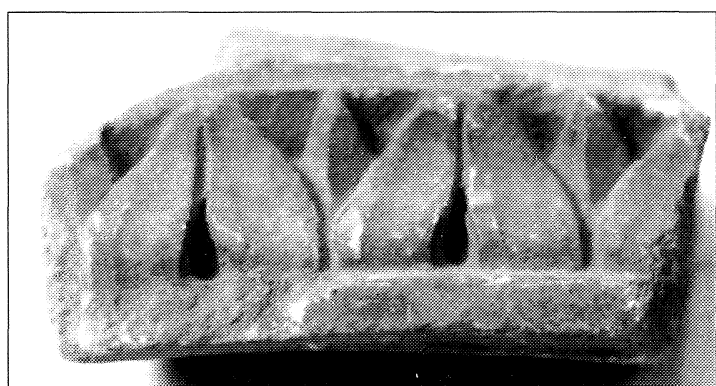

Fig. 11.-Cornisa de coronamiento de un nicho.

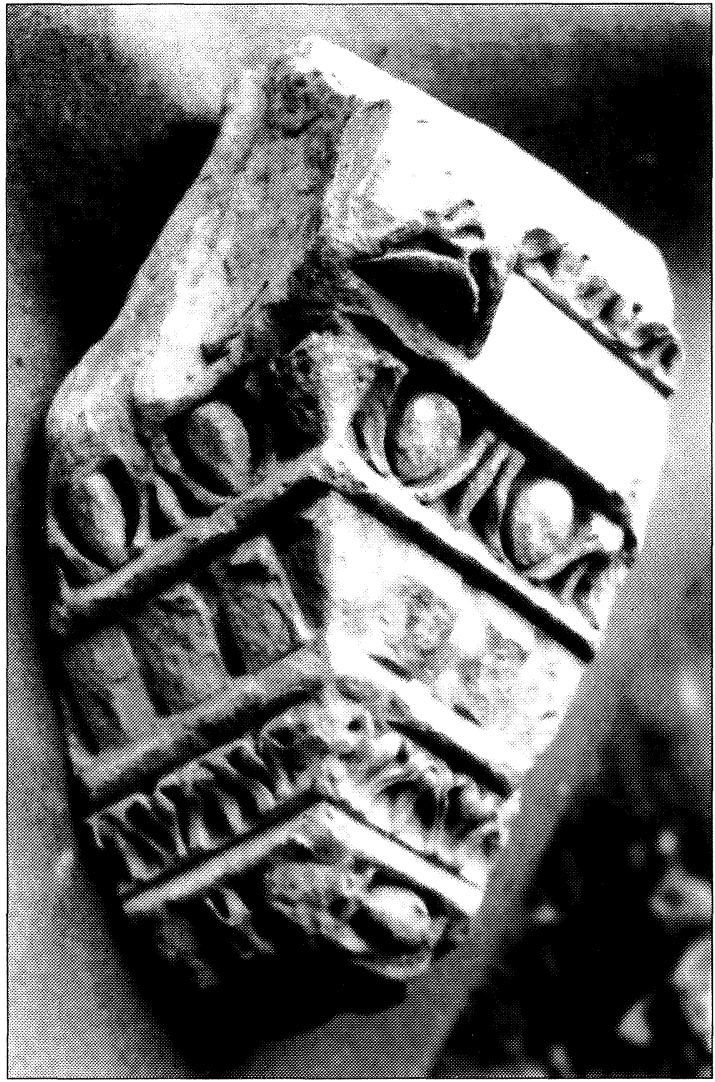

Fig. 12.-Cornisa de coronamiento de un nicho.

2.2. Templo del Forum Adiectum: la aparición del fragmento que ahora analizamos (fig. 13) nos proporciona una valiosa información sobre el edificio al que en su día perteneció. El fragmento ${ }^{17} \mathrm{se}$ adorna con una lengüeta en su centro, que nace de unas hojas y en cuyo lateral se desarrolla un canal. Descartadas otras posibles funciones del mismo llegamos a la conclusión de que éste no puede ser más

${ }^{17} \mathrm{Su}$ altura es de $12 \mathrm{~cm}$; ancho: $14 \mathrm{~cm}$; grosor: $6 \mathrm{~cm}$.

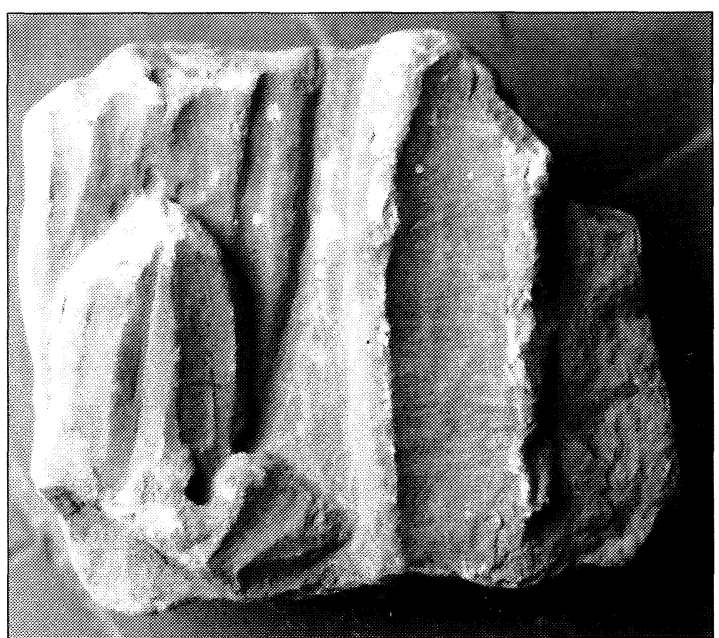

Fig. 13.-Fragmento de antefija en mármol.

que la parte central de una antefija marmórea de parecidas características a las que adornaban el templo de Mars Ultor en el Foro de Augusto ${ }^{18}$. Sus dimensiones, cercanas a las del modelo augusteo, confirman la monumentalidad de este edificio que debe ser identificado como un templo.

A partir de aquí estamos en condiciones de avanzar algo más en el conocimiento de este nuevo complejo formado por un pórtico y un templo situados en la calle Morería. La colosal dimensión de la antefija marmórea sugiere, a modo de hipótesis, la inserción en este mismo conjunto de una pieza ya publicada: nos referimos al colosal capitel del que se nos ha conservado un fragmento ${ }^{19}$ cuya procedencia, sin embargo, ignoramos. La vinculación entre ambas piezas está avalada no sólo por unas medidas colosales sino también por un similar estilo; a ello puede añadirse que, aunque entraría dentro de lo posible, difícilmente se construirán en un mismo periodo varios complejos edilicios de semejantes dimensiones. La perfecta relación en cuanto a dimensiones por parte de las piezas hasta ahora analizadas (antefija y capitel) corroboran su inclusión en el mismo edificio.

Pero además podemos establecer una relación entre el fragmento de capitel colosal y una pieza también publicada ${ }^{20}$, procedente de la calle Cruz Conde: el tallo de las hojas de ambas piezas, muy

18 V. Kockel, «Beobachtungen zum Tempel des Mars Ultor und zum Forum des Augustus», Römische Mitteilungen 90, 1983, 430 figs. 13 y 16, lám. 112, 3-4

19 Sobre sus características estilísticas, medidas y material vid. Márquez, cit. (n. 7), 88 s., lám. 15, fig. 4.

20 C. Márquez, Capiteles romanos de Corduba Colonia Patricia, Córdoba 1993, nº 39. 

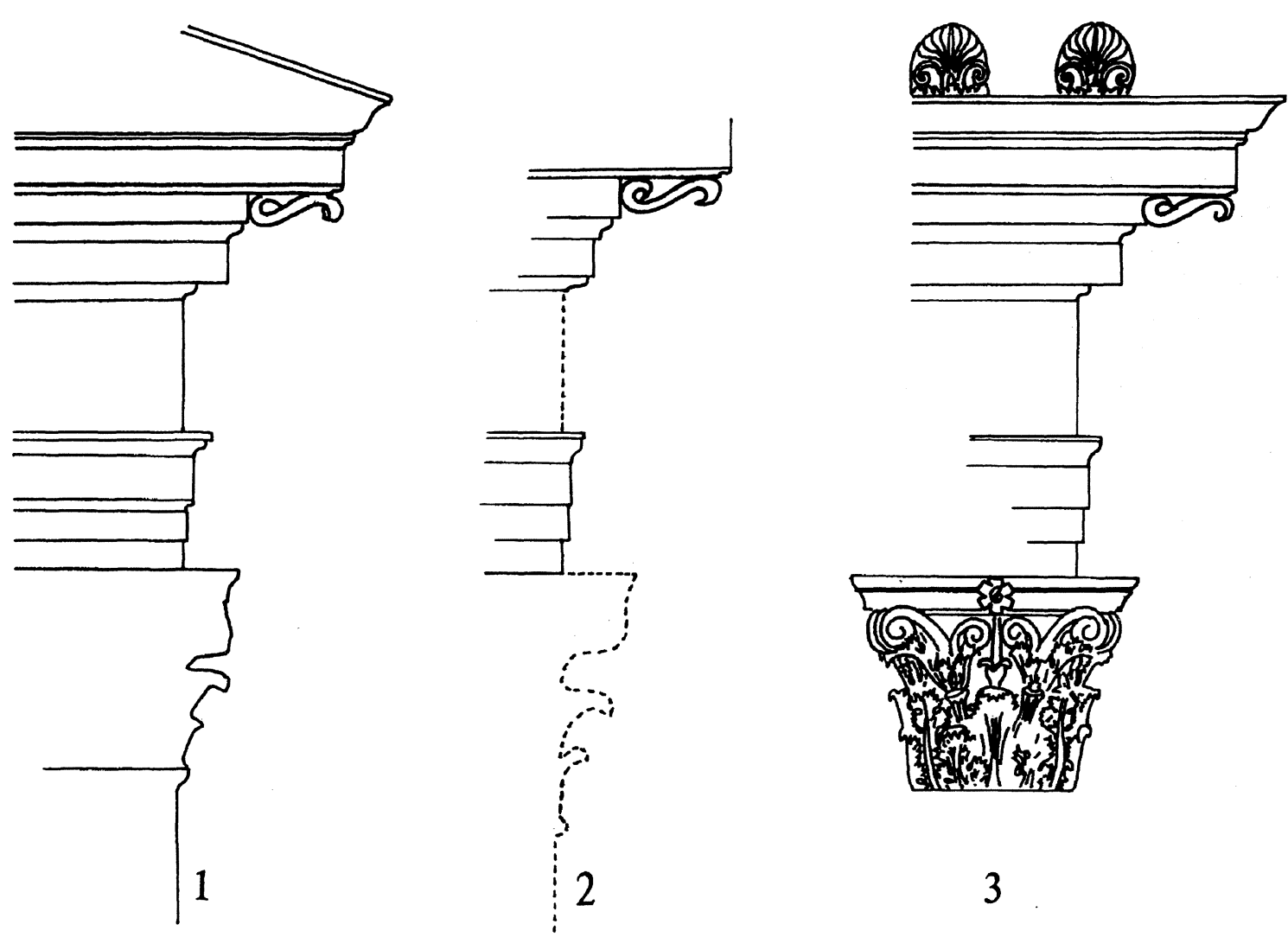

Fig. 14.-Sección del orden superior del templo de Cástor (1) y de la Concordia (2) en Roma; a la misma escala, restitución del orden del templo del Forum Adiectum en Colonia Patricia a través de las dimensiones del capitel colosal y la antefija.

potente, no se deja liso como en otros modelos augusteos ${ }^{21}$ sino que se señala de forma muy acusada el eje de igual modo que los capiteles del templo de Mars Ultor ${ }^{22}$, con los que coincide, además, en el modo en que entran en contacto los extremos de las hojitas y en las zonas en forma de gota de agua. La dimensión de este nuevo capitel es, aproximadamente, un tercio inferior a la pieza colosal, por lo que éstos podrían corresponder a los del templo y el más pequeño al pórtico que circunda la plaza. Este conjunto se vincularía con el foro colonial a modo de Forum Adiectum y estaría situado en su flanco sur (fig. 1, $\mathrm{n}^{\circ}$ 5).

Podemos insertar este edificio dentro de la arquitectura augustea de la capital del imperio. En la figura 14 se desarrollan, a la misma escala, el orden de dos de los Aurea Templa (templo de Cástor y templo de la Concordia en el Foro romano) junto al templo de la calle Morería en Córdoba. La similitud

${ }^{21}$ W. D. Heilmeyer, Korinthische Normalkapitelle, Heidelberg 1970, lám. 44, 1-2.

22 Ibidem, lám. 3-3. en sus dimensiones y la labra perfecta de la que hace gala el fragmento de capitel y de antefija (téngase en cuenta a qué altura se ponía esta última y obsérvese lo bien labrada que está) nos induce a creer que sería un taller venido de Roma el que se encargó de levantar todo el complejo en el periodo augusteo-tardío o tiberiano, que es cuando fechamos el mismo. Si bien se conocía el mármol en edificios emblemáticos de Córdoba, no había una verdadera tradición que permitiese la formación de un dominio en la materia capaz de realizar un verdadero «capolavoro» como el capitel antes citado. Podríamos imaginar que tras la construcción de los Aurea Templa en Roma, alguno de los talleres que no recibieron más encargos en la Urbs fueron llamados a la capital de la Bética para la erección de este complejo edilicio situado en las cercanías del foro colonial.

Cabe también una comparación con los complejos forenses de las otras capitales provinciales hispanas, Tarragona y Mérida, siendo el foro de Augusto el modelo común para todas ellas. En Mérida, 
el denominado «Foro de mármol» ${ }^{23}$ sólo se conoce parcialmente y queda por concretar con detalle su función. No ocurre lo mismo en Tarragona ${ }^{24}$, donde se define este espacio sin lugar a dudas como recinto de culto imperial provincial; pero existe un nexo de unión entre los tres al observarse los vínculos con el foro de Augusto en lo que a ornamentación escultórica se refiere, y es precisamente en la presencia de estas grandiosas esculturas ${ }^{25}$ (téngase presente que en esta misma calle Morería apareció la gigantesca escultura loricata de la Colección Tienda) donde pueden confirmarse los vínculos entre las tres capitales hispanas y su común modelo romano. En consecuencia, el edificio aquí aludido podría ser considerado templo de culto imperial de la Colonia, si bien esta propuesta no pasa de ser una hipótesis. (Véase addenda al final del trabajo).

Vemos, en resumen, cómo en un momento inmediatamente posterior al augusteo se suscita (quizás por parte de las elites locales) la necesidad de construir un nuevo edificio colosal, a imagen del templo de Mars Ultor en Roma y comparable con otros Aurea Templa, con una decoración escultórica no menos colosal; podríamos ver en ello una apuesta por parte de la elite local que, para adherirse a la política central y de la familia imperial, construye un magno edificio para rendir culto al princeps por parte de la colonia, copiando programas que serán perpetuados años después por las otras capitales de provincia hispanas. Esto requería un amplio espacio en el centro neurálgico de la colonia y dónde mejor que en los aledaños del foro para realizar su proyecto; a tal fin se requisan construcciones domésticas al sur del foro colonial ${ }^{26}$, para construir una plaża conectada con el foro colonial pero no abierta al mismo ${ }^{27}$, rodeada de un

${ }^{23}$ W. Trillmich, «Los tres foros de Emérita Augusta y el caso de Córdoba» en P. León, cit., 175 ss.

${ }^{24}$ R. Mar, «El Recinto de culto Imperial de Tarraco y la Arquitectura Flavia» en R. Mar (ed.), Els monuments provincials de Tarraco. Documents d'Arqueologia Classica 1, 1993.

${ }_{25} \mathrm{La}$ colosal escultura cordobesa de la colección Tienda representa a Eneas o Rómulo, mientras que en el foro emeritense se confirma la presencia de Eneas. Vid. W. Trillmich, "Aspekte der "Augustus-Nachfolge" des Kaisers Claudius" en V.M. Strocka (Hrsgb.), Die Regierung des Kaisers Claudius (41-54 n. Chr.). Umbruch oder Episode?, Koll. Freiburg (1991), Mainz am Rhein 1994, 69 ss

26 A las que pudo pertenecer el opus signinum detectado «en los pozos de cimentación» de la calle Díaz del Moral 4. Vid A. Ibáñez, cit. (n. 4).

${ }^{27}$ El muro de Díaz del Moral lo atestigua. Ibidem. El complejo actuaría a modo de Forum Adiectum como en Arles, curiosamente construido en el periodo tiberiano y unido al foro augusteo de la colonia. Las concomitancias con el caso cordobés son evidentes. Vid. P. Gros, «Un programme augustéen: le centre monumental de la colonie d'Arles», Jahrbuch des Deutschen Archölogischen Instituts 102, 1987, 357 ss. pórtico y en cuya cabecera se erigió el fastuoso edificio religioso. Que el conjunto llegase hasta el decumano máximo es algo que no puede demostrarse de forma directa pero podríamos preguntarnos porqué el sector occidental del propio decumano no va en línea con el sector oriental sino que se sitúa mucho más al sur. Pudo, quizás, adoptar este tramo nuevo después de las transformaciones a las que acabo de hacer referencia. La aparición en la misma calle Morería de la estatua loricata y otras 28 indica que sería éste el flanco más importante del recinto y donde se ubicaría el templo.

2.3. Tholos forense: el fragmento de cornisa de la fig. 15 formó parte en su día de un edificio circular que, habida cuenta de las notables dimensiones de la pieza ${ }^{29}$ y del lugar de hallazgo (cercano o en el propio foro de la colonia), pudo ser parte de una tholos. Podemos comparar nuestra pieza con el templo de Roma y Augusto construido en el año 27 antes de Cristo en la Acrópolis ateniense, si bien es cierto que las dimensiones de sus cornisas rebasan levemente las de la pieza cordobesa ${ }^{30}$. Por otro lado no hay que olvidar que funciones más ornamentales que estrictamente religiosas se dan en la tholos que cubre el pozo en el foro triangular de Pompeya ${ }^{31}$, ni que tal ornamentación se entiende en la actualidad como la monumentalización de un pozo existente en el foro pompeyano imitando el mundus del Foro romano ${ }^{32}$. En Roma contamos con otro edificio de similares características arquitectónicas como es el templo de Vesta ${ }^{33}$, lo que parece dar a entender que el mismo tipo arquitectónico actúa de «protector» de los elementos (fuego y agua) y al mismo tiempo como señal de atención visual a los visitantes.

${ }^{28}$ Como un pedestal colosal conservado en el Museo con el $\mathrm{n}^{\circ}$ de registro 23.543 .

${ }_{29}$ El fragmento mide $21 \mathrm{~cm}$. de alto y es sólo una parte de la cornisa.

${ }^{30}$ G.A.S. Snijder, De Tempel van Roma en Augustus en het Erechtheum op de Acropolis te Athene, Medeelingen van het Nederlandsch Historisch Institut te Rome Den Aag 1923; véase una reconstrucción en L. Schneider, Ch. Höcker, Die Akropolis von Athen, Köln 1990, p. 230, fig. 134.

${ }_{31}$ A. de Vos, M. de Vos, Pompei, Ercolano, Stabia. Guida archeologica Laterza, Roma 1982, p. 62; una idealizada reconstrucción la de P. Zanker, Pompeji. Stadtbild und Wohngeschmack, Mainz am Rhein 1995, p. 55, fig. 15.

${ }^{32}$ M. Verzar, «L'Umbilicus Urbis», Dialogui di archeologia, IX-X 1976, p. 378 ss.

${ }_{33}$ El aspecto que presenta en la actualidad (tras la moderna restauración de 1930) se debe a la refectio que en época severa hizo Iulia Domna, esposa de Septimio Severo; los cimientos y el podium datan, sin embargo, de época augustea. Vid. E. Nash, Pictorial Dictionary of Ancient Rome II, Tübingen 1968, p. 505 ss.; F. Coarelli, Roma, Guide archeologiche Laterza, Bari 1988, p. 81 ss. 


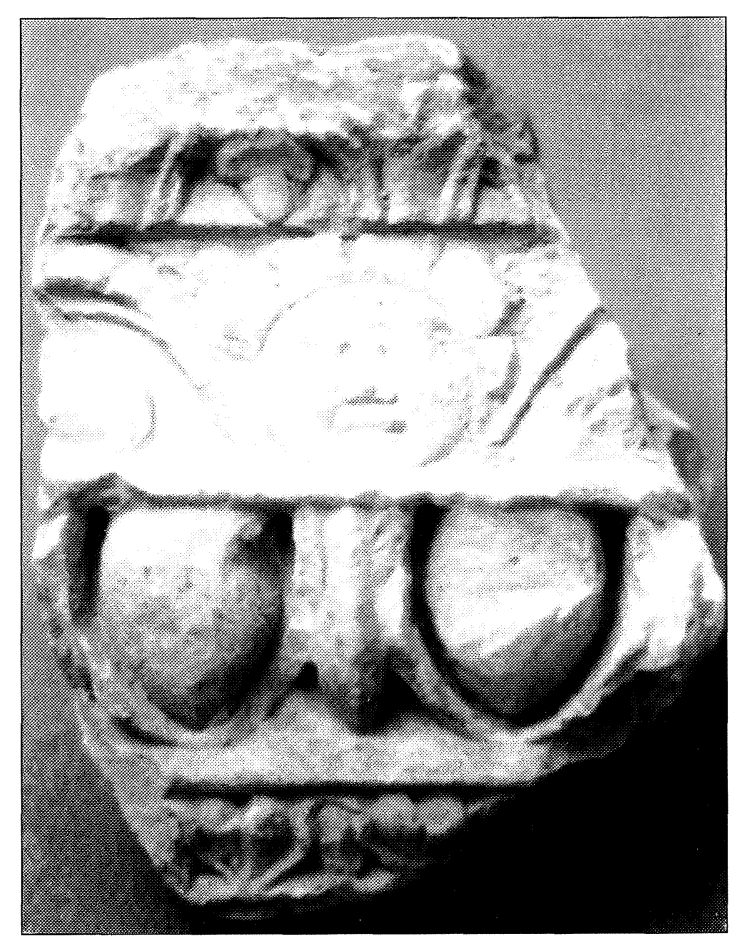

Fig. 15.-Fragmento de cornisa circular.

No sería, pues, simple casualidad el hallazgo de esta pieza en la zona del foro. No tenemos, obviamente, ningún indicio firme para interpretar el significado de la que pudo ser tholos cordobesa aunque es inevitable resaltar la pertenencia de casi todos estos edificios circulares a complejos sacros ${ }^{34}$.

\section{Altos de Santa Ana (Figura 1, n 3).}

En la parte más alta de la ciudad se asentaría un conjunto formado por una plaza ${ }^{35}$ con edificios cuya grandiosidad queda demostrada a través de un fragmento de arquitrabe (fig. 16) que, con $22 \mathrm{~cm} \mathrm{de}$ altura, iguala o supera los coronamientos de algunos Aurea Templa ${ }^{36}$. En la misma zona se ubica un edificio de culto a Diana (vid. infra). Con anterioridad a esta imagen de época imperial podemos intuir la

${ }^{34}$ EAA voz Tholos (G. A. Mansuelli).

35 A. U. Stylow, «Apuntes sobre el urbanismo de la Corduba romana» en W. Trillmich, P. Zanker (ed.) Stadtbild und Ideologie, München 1990, 259 ss.

${ }^{36}$ El coronamiento del arquitrabe del templo de Mars Ultor en el Foro de Augusto es de $19 \mathrm{~cm}$. Las molduras en cima reversa de su cornisa son inferiores; tanto el templo de la Concordia como el de Vespasiano tienen muy parecidas medidas a las de la pieza cordobesa $(22$ y $21,7 \mathrm{~cm}$ respectivamente). Vid. Töbelmann, Römische Gebälke, Atlas lám. IV y VI; V. Kockel, cit. (n. 16), lám. 15; St. de Angelis, Templum Divi Vespasiani, Roma 1992, fig. 80.

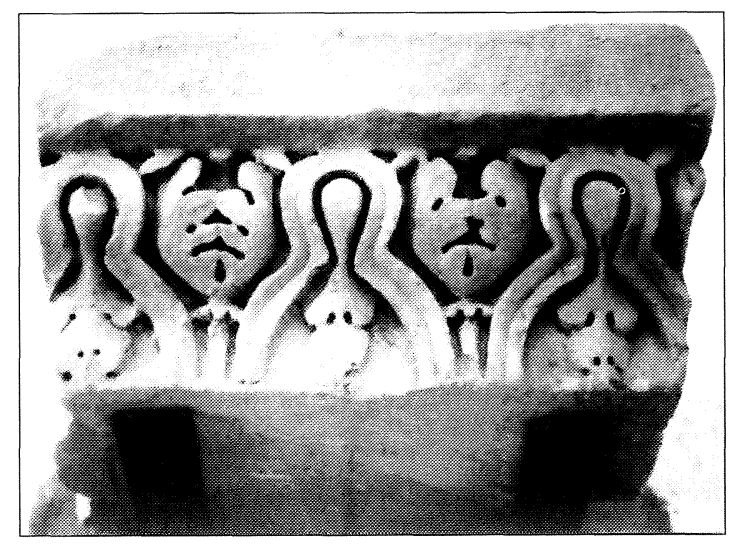

Fig. 16.-Fragmento de arquitrabe de edificio público.

importancia que desde el momento mismo de la fundación de la ciudad se le otorgó a esta zona: algunos elementos arquitectónicos (fig. 17) muestran la primera monumentalización de esta zona en época republicana, donde podemos situar un recinto religioso de indudable importancia y similar a la de muchas ciudades centro-itálicas ${ }^{37}$.

\section{Santuarios y Templos}

\subsection{Santuario republicano (Figura $1, n^{\circ} 4$ )}

Tres tambores de fuste ${ }^{38}$ (fig. 18), hechos en piedra caliza con veinte canales que conservan todavía una gruesa capa de estuco, aparecieron en un solar extramuros de la ciudad republicana; en la península ibérica podemos confrontar estas piezas con dos de los edificios augusteos mejor conservados y conocidos: el templo de Diana en Mérida, cuyo fuste es algo más estrecho ${ }^{39} \mathrm{y}$ el templo de Barcino que es mayor ${ }^{40}$. Idénticas son, por otro lado, las medidas de nuestras piezas y el tambor de pilastra del templo republicano de Ampurias ${ }^{41}$. Las dimensiones de las piezas avalan, sin lugar a dudas, su pertenencia a un edificio de carácter público con

${ }^{37}$ P. Zanker (ed.), Hellenismus in Mittelitalien, Koll. Göttingen 1976.

38 Sus alturas oscilan de 36 a $43 \mathrm{~cm}$ y sus diámetros van de 93.5 a $97 \mathrm{~cm}$.

39 J. M M Álvarez, «El Templo de Diana», Cuadernos de Arquitectura Romana I, 1991, 90. J. L. de la Barrera, cit. (n. $15)$.

40 J. Puig i Cadafalch, L'arquitectura romana a Catalunya, Barcelona 1934 fig. 97. M A. Gutiérrez Behemerid, «El templo romano de Barcino. Análisis de la decoración arquitectónica», Cuadernos de arquitectura romana I, 1991, $95 \mathrm{ss}$.

${ }^{41}$ De inicios del siglo I a. de C. Vid. J Aquilué et alii, El Forum Romà d'Empuries, Barcelona 1984, fig. 28. 

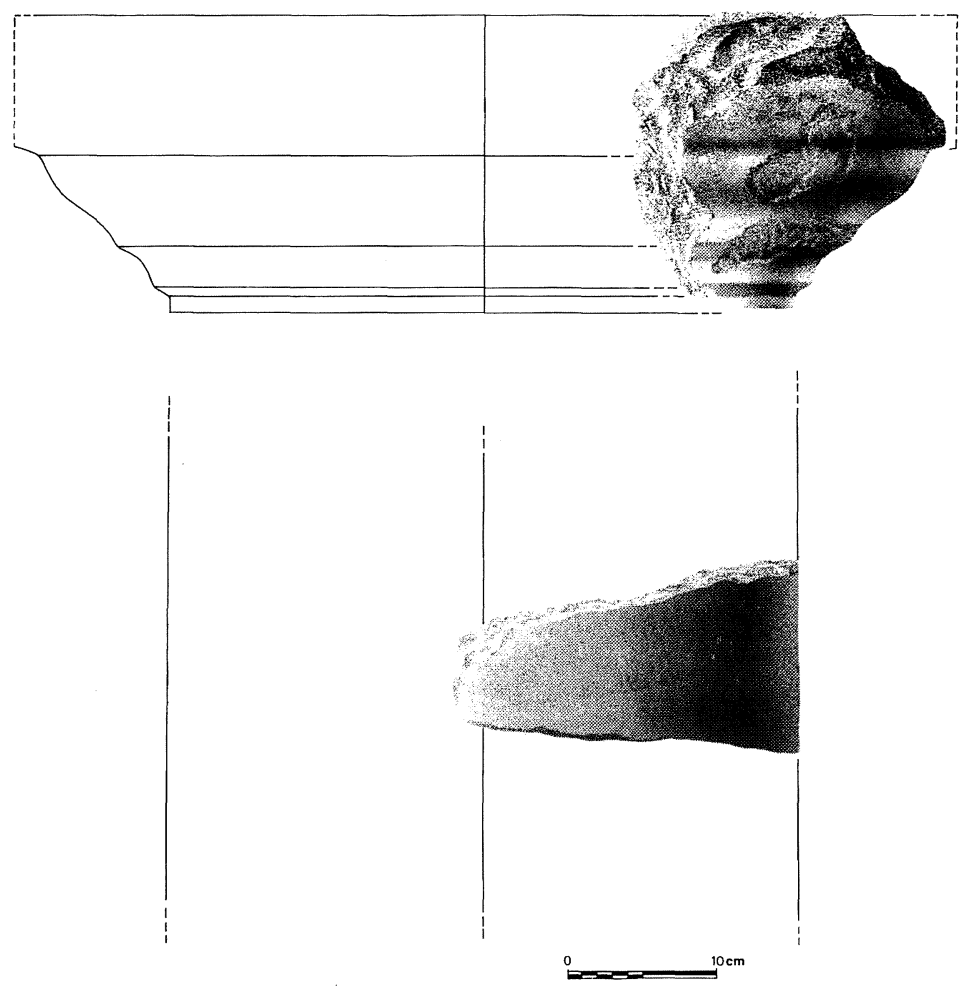

Fig. 17.-Capitel toscano.

fustes que medirían entre 7 y 9 metros. De lo hasta aquí comentado queda clara la asignación de estos tambores a un edificio monumental, con toda probabilidad un templo. Los paralelos a los que nos hemos referido no han sido tomados al azar sino que todos ellos pertenecen al ámbito cronológico aproximado en el que estimamos debe ser incluido nuestro edificio. Una rápida comparación entre el tipo de material (piedras locales); un similar número de estrías con una gruesa capa de estuco nos indica un mismo momento para la edificación de los

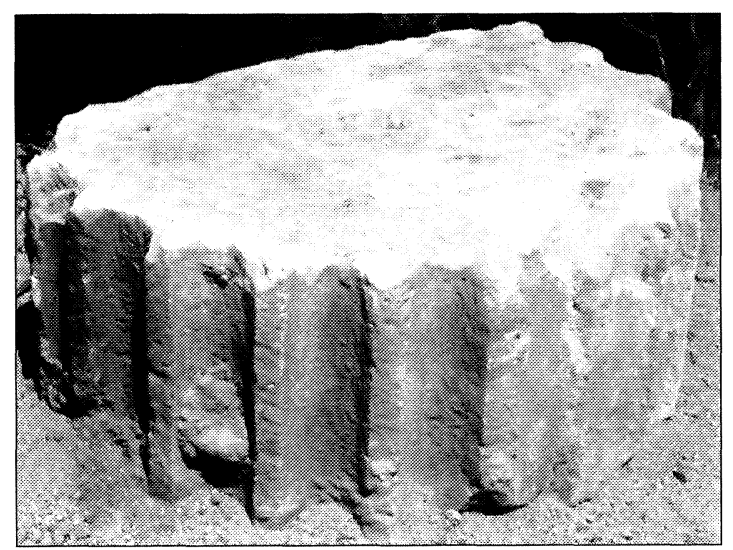

Fig. 18.-Fuste en piedra caliza. tres edificios hispanos, o sea, el periodo republicano tardío y el augusteo reciente. Un segundo testimonio de su temprana cronología nos lo proporcionan las circunstancias de su hallazgo: tanto estos tres tambores como otros que no fueron extraídos formaban parte de la cimentación de la muralla augustea que se detectó en este solar ${ }^{42}$.

Una vez demostrada la monumentalidad del edificio y su cronología pasaremos a analizar su función y ubicación. Ya se dijo que las piezas fueron halladas extramuros de la Corduba republicana (figura 1 , $\left.n^{\circ} 4\right)$ y en un punto intermedio entre ésta y el puerto fluvial ${ }^{43}$, reaprovechadas en la construcción de la muralla augustea. Ante ello se nos plantean dos posibilidades sobre su procedencia original: que las piezas se reaprovecharan en un punto cercano al edificio al que pertenecieron o bien que hubieran sido trasladadas de otro lugar (posiblemente del interior de la ciudad). Si los tambores se hallan cerca del edificio original para el que fueron labrados tendríamos que responder inmediatamente a una cuestión de vital trascendencia: ¿qué hace un templo fuera del pomerium? Y además, ¿existe alguna relación entre el desmonte del edificio original y la ampliación urbana de Córdoba con la construcción de la muralla augustea? Se conocen algunos ejemplos seguros de santuarios republicanos construidos fuera del pomerio. En Brescia, en el mismo lugar donde luego se alzaría el capitolio flavio, se levantó en una explanada un grupo de pequeños templos dedicados a Venus, Fortuna, Ceres y Spes, vinculados con toda probabilidad a operaciones que se realizaban en el vecino puerto fluvial $^{44}$. El mismo carácter tiene el grupo de cuatro templetes situados en una explanada cercana a Ostia ${ }^{45}$. Otro ejemplo podría proceder del templo rec-

${ }^{42}$ Agradezco a $\mathrm{D}^{\mathrm{a}}$ Nuria López Rey y D. Eduardo Ruiz Nieto esta información. Sobre el trazado de la muralla republicana y de la ampliación augustea vid. A. Ventura et alii, «Análisis arqueológico de la Córdoba romana: resultados e hipótesis de la investigación» en P. León, cit., 91 s.

${ }^{43} \mathrm{Si}$ se acepta su ubicación en el actual Alcázar, ibidem, fig. 28.

${ }^{44}$ A. Frova, Catalogo della Mostra Brescia Romana I, Brescia 1979, 214.

${ }^{45}$ F. Zevi, «Monumenti e Aspetti culturali di Ostia repubblicana» en P. Zanker, cit., 53. 
tangular del Foro Boario en Roma, atribuido tradicionalmente a la Fortuna Viril y que fue en realidad dedicado a Portunus, si bien parece probable pensar que las murallas servianas siempre lo resguardaron ${ }^{46}$. Así podemos intuir, como primera hipótesis, la existencia de un santuario en un lugar cercano al puerto fluvial y relacionado con él, santuario que se destruye probablemente por las tropas cesarianas o bien como consecuencia de la construcción de la muralla.

Pero existe una segunda posible localización de este templo-santuario; si este material ha sido transportado allí desde un punto alejado hemos de pensar que, por las dimensiones del edificio, éste sería uno de los edificios religiosos principales, si no el de más rango, de los existentes en la ciudad en este periodo, al igual que sus paralelos emeritense y barcinonense. En este caso su lugar de origen habría que buscarlo con toda probabilidad en el foro de la colonia.

De cualquier forma, al no contar con más información, sería arriesgado por nuestra parte defender a ultranza alguna de las hipótesis planteadas. Quede constancia de las dimensiones más que notables del edificio que equipara la arquitectura tardorrepublicana y augustea de Córdoba con otras ciudades que han contado con la suerte de poseer soberbios edificios como el templo de Diana en Mérida y el templo de Barcelona.

\subsection{Templo de Diana (Figura 1, 5)}

La feliz circunstancia de contar con una basa decorada (figs. 19-20) que aprovechó un pedestal con una inscripción dedicada a la diosa Diana ${ }^{47}$, nos permite unos comentarios sobre la detección de un lugar de culto a la referida diosa. Queda claro que esta basa se realizó aprovechando el pedestal en un momento que no conocemos, pero siempre posterior a la mitad del siglo i de C., cuando aquél se fecha. Sin embargo plantea una particular inquietud observar que esta basa, labrada quizás en la antigüedad tardía, copia detalladamente un modelo augusteo: el del Templo de Apolo in

46 «L'aedes Portum in Porto Tiberino o ad pontem Aemilium, ricordata nel I se. A. C... e ormai da tempo riconosciuta nel tempio ionico del foro Boario (detto della Fortuna Virile), che nella sua forma attuale risale al I secolo a. C.». A. Colini, C. Bruzzetti, «Aedes Portunus in Porto Tiberino», Bulletino Comunale XCI 1986, 7 ss.

${ }^{47}$ CIL II $2 / 7,222$. J. A. Garriguet, Testimonios arqueológicos del culto imperial en Colonia Patricia Corduba. Tesis de Licenciatura (inédita), Universidad de Córdoba 1996, 280 ss., lámina 81 .

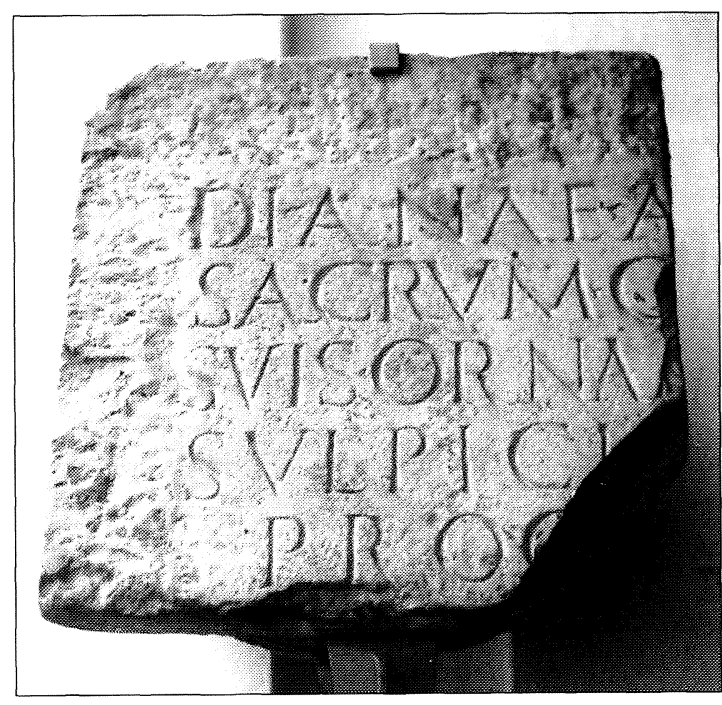

Fig. 19.--Inscripción dedicada a Diana.

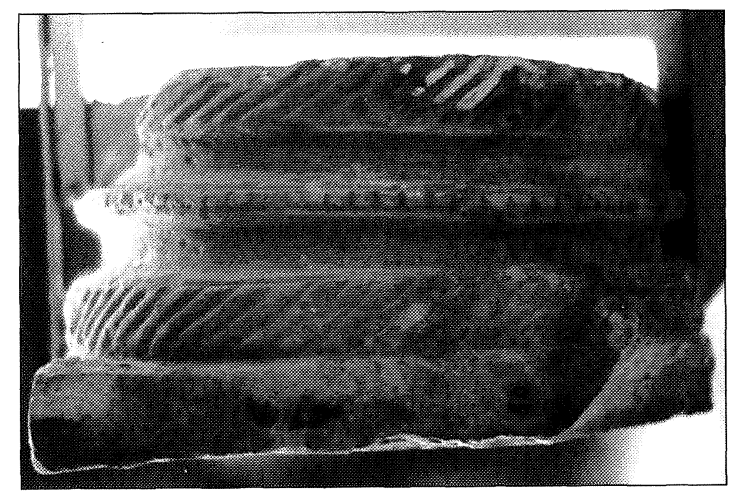

Fig. 20.-Basa reaprovechada en el pedestal anterior.

Circo $^{48}$. En efecto, los sencillos trazos en los toros no hacen más que imitar con una labra poco afortunada el adorno en forma de cuerda de las basas del templo augusteo. El estrecho toro central, a su vez, imita las perlas que flanquean los toros del ejemplar romano.

¿Habría que pensar en que una circunstancia casual fue la que llevó a adornar una basa cordobesa siglos después a la manera de un modelo urbano? Más lógico es pensar que probablemente la pieza cordobesa se labró para llevar a cabo una refectio del edificio de culto a Diana, en un momento ya tardío, cuando era difícil conseguir material marmóreo

48 P. Gros, Aurea Templa, Roma 1976 p. 211 ss., p. 227, lám. LX. E. la Rocca, Amazzonomachia. Le sculture frontonale del tempio di Apollo Sosiano, Roma 1985, p. 85, fig. 3. A. Viscogliosi, Il tempio di Apollo in Circo e la formazione del linguaggio architettonico augusteo, Roma 1996, 43 ss. fig. 42 . 
para reponer piezas arquitectónicas dañadas. Ante tal circunstancia, los encargados de la obra no sienten reparo alguno en cortar un pedestal situado en el edificio o en su entorno para extraer el material necesario. Pero ¿por qué recurren a esa ornamentación? La respuesta es sencilla: porque no hacen más que copiar las basas originales de ese edificio, algunas de las cuales se conservarían todavía in situ. Y serían estas basas originales, casi con toda seguridad trabajadas en mármol, las que copiaron en su momento el modelo de las basas del templo de Apolo in Circo. Llegados a este punto habría que fechar el edificio cordobés en un primer momento de época imperial hacia las postrimerías del principado de Augusto o inicios del de Tiberio, toda vez que se alzaría, lógicamente, antes de la dedicación de cualquier pedestal a la diosa.

El desconocimiento de las circunstancias en que se halló la pieza cordobesa ${ }^{49}$ impide saber si se encontró in situ o no. Contamos, sin embargo, con una preciosa información para ubicar este centro de culto en las inmediaciones del conocido como Foro Provincial; en concreto, en el solar $n^{\circ} 10$ de la calle Ángel de Saavedra se realizaron unas excavaciones que dieron como resultado la aparición de unos muros que han sido interpretados (con buen criterio, creemos) como cimentación del pórtico de un edificio público ${ }^{50}$; la vinculación con el culto de Diana a través de un pedestal y la constatación arqueológica de una refectio en los inicios del siglo in d. de C. permiten avalar no sólo la existencia del Aedes Dianae, sino también conocer cuándo se construyó y las distintas fases edilicias que ha sufrido. De la calidad de otros materiales constructivos allí localizados — placas de mármol cipollino, columnas de granito, las mismas basas originales labradas presumiblemente en mármol, etc.- se infiere, por otra parte, la magnificencia que pudo ostentar el edificio del siglo III, dato del mayor interés por ser ésta una fase mal conocida de la edilicia cordobesa.

\section{El teatro (Figura $1, \mathrm{n}^{\circ} 6$ )}

Hasta hace apenas dos años no contábamos con más edificios conservados que el templo romano de la calle de Claudio Marcelo. En este periodo, los trabajos que el Seminario de Arqueología de la Uni-

${ }^{49}$ La procedencia de la pieza en la colección del Marqués de Villaverde en la Plaza de los Aguayos no es, evidentemente, la original.

50 A. Ventura, «Resultados del seguimiento arqueológico en el solar de C./ Ángel de Saavedra n 10, Córdoba», Anales de Arqueología Cordobesa 2, 1991, p. 262 s., fig. 1.

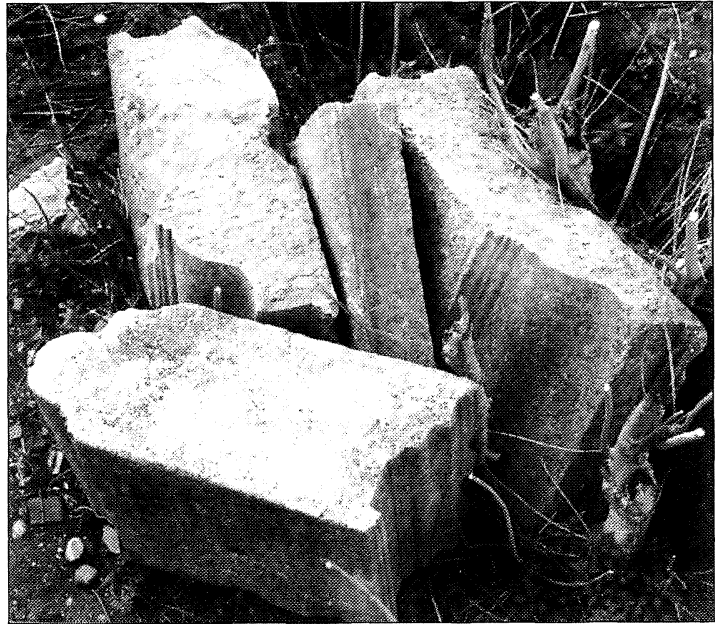

Fig. 21.-Cornisas de doble frente de la fachada exterior de la cavea del teatro.
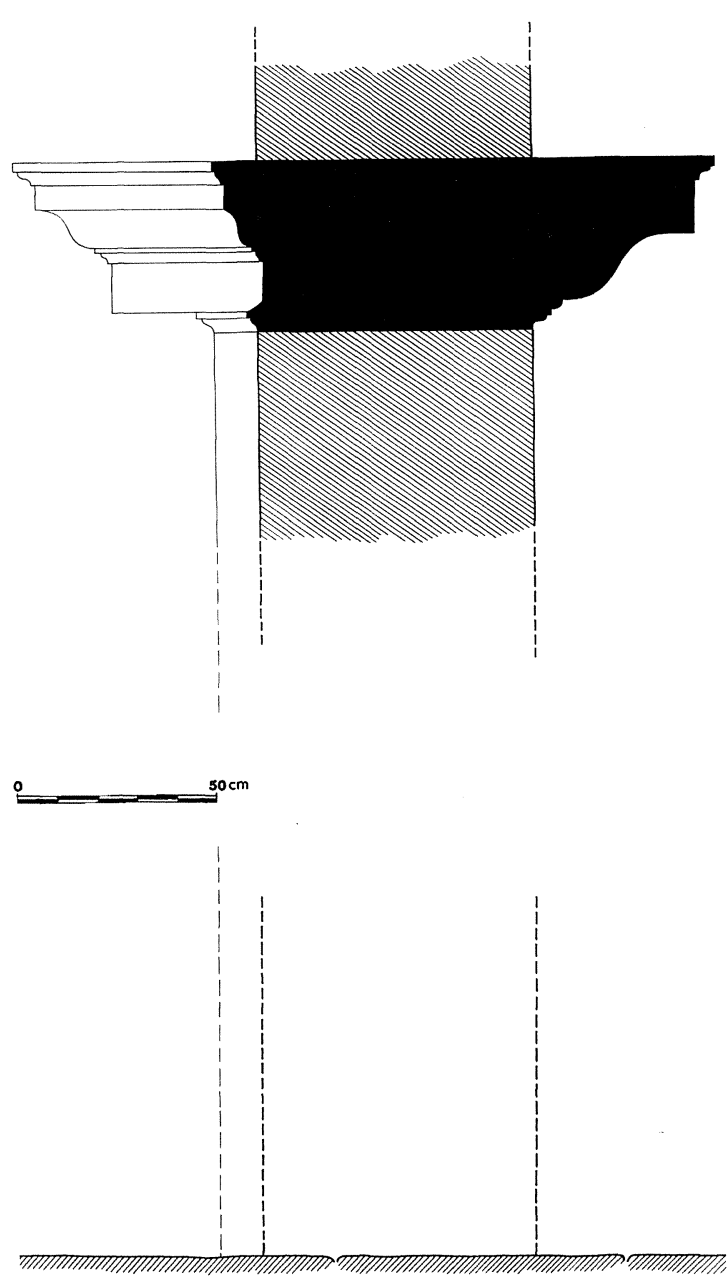

Fig. 22.-Cornisas de doble frente de la fachada exterior de la cavea del teatro. 


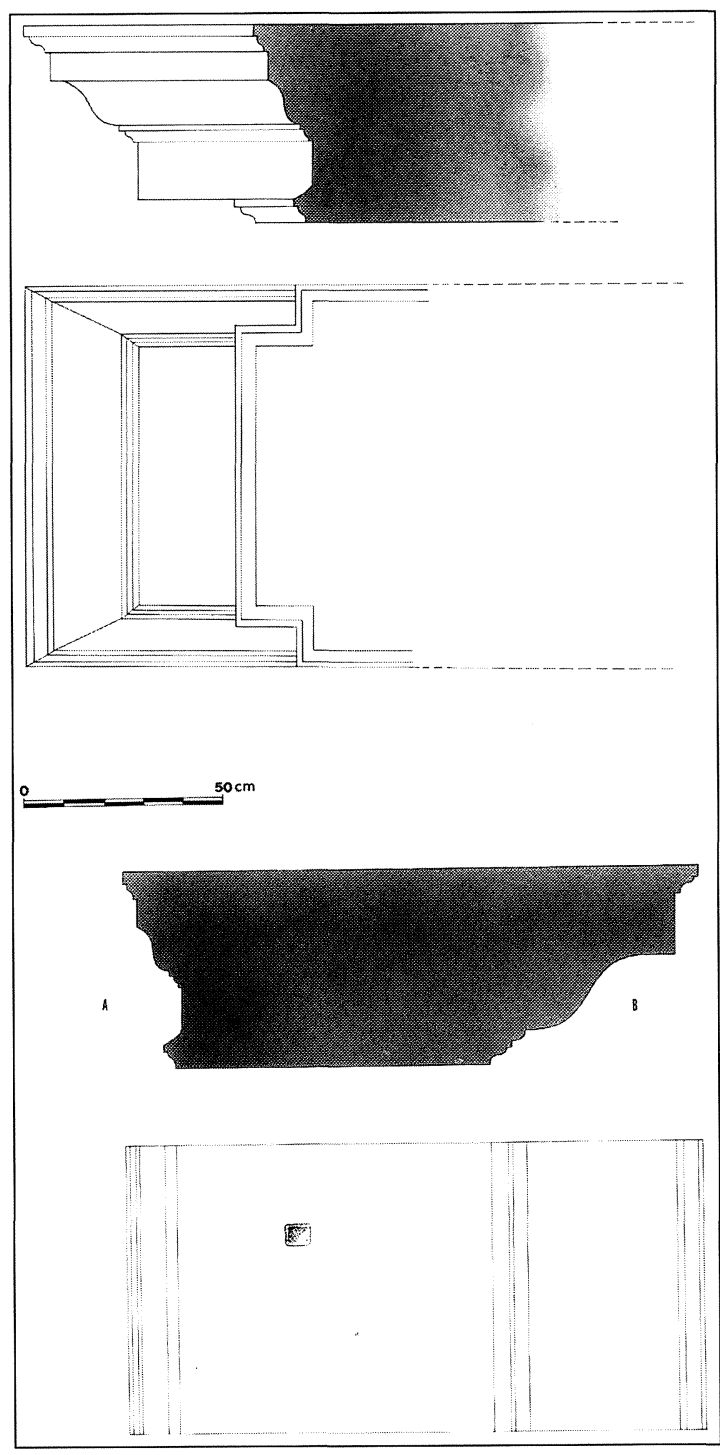

Fig. 23.-Cornisas exteriores de doble frente de la cavea del teatro.

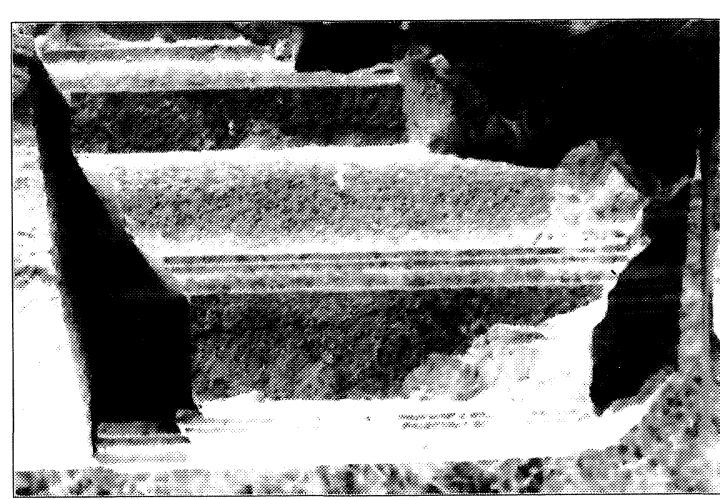

Fig. 24.-Cornisa decorada de orden toscano de la fachada del teatro. versidad de Córdoba desarrolla en solares del Museo Arqueológico Provincial han puesto al descubierto uno de los edificios más importantes de cualquier ciudad romana: el teatro ${ }^{51}$. Hemos de hacer constar que la casi totalidad de las piezas que aquí estudiamos estaban diseminadas por el solar, por lo que desconocemos su origen exacto y el material con el que se relacionaban estratigráficamente.

El material aquí analizado procede por un lado de diversas excavaciones realizadas en la zona y por otro de los fondos del Museo. Su procedencia permite acercarnos visualmente a la apariencia del teatro en dos de sus zonas más relevantes: la fachada del graderío y la frons scaenae. Queremos incidir en que los resultados de esta primera aproximación a la arquitectura del complejo arquitectónico aquí analizado deben ser entendidos como provisionales, a la espera de que futuras intervenciones aporten mayor información que los amplíe, matice o corrobore.

\subsection{Fachada del graderío y de las plazas}

El material arquitectónico aparece en los solares excavados en las campañas de 1994 y 1995 (este último como excavación de urgencia realizada por $\mathrm{D}^{\mathrm{a}}$ Inmaculada Carrasco), solares alejados entre sí unos cien metros. En ambas zonas han aparecido algunas piezas de idénticas características, como son las cornisas de doble frente (figs. 21-22) hechas en piedra de mina (piedra caliza micrítica); en concreto en el patio del Museo se conservan 18 piezas de este tipo, mientras que en el solar de la calle Rey Heredia han aparecido otras tres. Éste es un dato importante porque demuestra que estos elementos adornaban una estructura que se localizaba, al menos, en estos dos puntos, estructura que no puede ser otra que la fachada exterior de la cavea. Ninguna otra parte del edificio puede tener tal desarrollo.

Como confirmación de esta hipótesis podemos exponer un dato complementario: piezas de estas mismas características se conservan en la actualidad en tres puntos más de la zona: patio del ciprés del Museo, solar aledaño a la Plaza de J. Páez y en esta misma plaza. La dispersión de estas piezas confirma su pertenencia al muro circular de cierre de la $c a$ vea, pues han aparecido tanto al interior como al exterior del mismo. Sin embargo, mucho más difícil es intuir su ubicación exacta. El hecho de adornar ambos frentes de modo diverso indica una doble

${ }^{51}$ Un avance de los primeros resultados en A. Ventura, $\mathrm{P}$. León, C. Márquez, «Roman Córdoba on the light of the new discoveries», Journal of Roman Archaeology (en prensa). 
función. La cara decorada (fig. 23-a) con el orden toscano decoraría, presumiblemente, la fachada exterior. La otra, formada por una gran ménsula (fig. 23-b), serviría para sostener algo, bien la bóveda de hormigón de una de las galerías o bien para la techumbre de un pórtico.

Como todas las fachadas de teatros, el nuestro debió contar con varios cuerpos correspondientes a distintos órdenes; sin embargo, no se han encontrado testimonios de su presencia a excepción de dos cornisas molduradas con un capitel toscano (fig. 24) de pilastra correspondiente al mismo orden y al mismo cuerpo que las vistas con anterioridad. Parece lógico pensar que éste sería el cuerpo superior pues sus elementos se han encontrado, en ocasiones, en unas cotas elevadas, consecuencia del desplome de la fachada cuyos elementos superiores se alejan en la caída de las cercanías del muro.

Dato de gran interés es el proporcionado por algunas de estas cornisas, donde se inscriben algunas letras. Dos piezas se marcan con las siglas M P en la zona decorada con el orden toscano (fig. 25). Una tercera cornisa tiene en su cara superior una numeración claramente vinculada al control fiscal realizado en las canteras de origen. Mayor dificultad reviste la explicación de las siglas M P como las del artesano que labró las piezas (aunque esta explicación se invalida habida cuenta de la falta de siglas en la mayoría de las cornisas); quizás sean las siglas de una importante familia de la ciudad que ayudó a sufragar los gastos de construcción del edificio, hipótesis ésta que se ve confrontada por paralelos en teatros italianos del mismo periodo.

Elemento importante para un análisis estilístico son los capiteles, de los que se han encontrado cuatro ejemplares. El más interesante (fig. 26) sin duda es el procedente del solar excavado en la calle Rey Heredia. Se trata de un capitel corintio de columna de gran tamaño (su altura es de $66 \mathrm{~cm}$.) y elaborado en un mármol blanco de grano muy fino (casi con

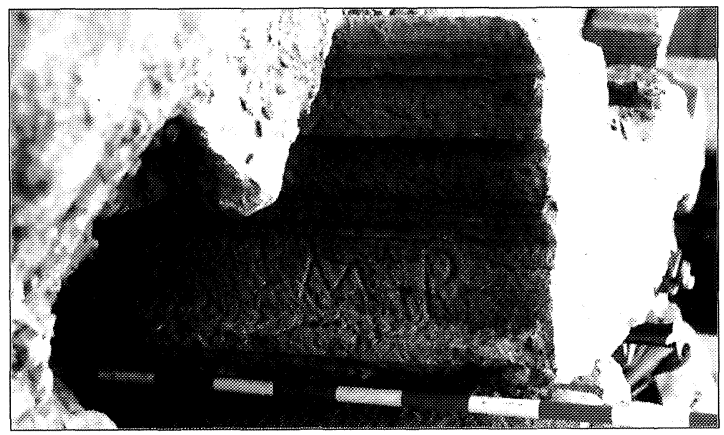

Fig. 25.-Cornisa de doble frente con la inscripción M P.

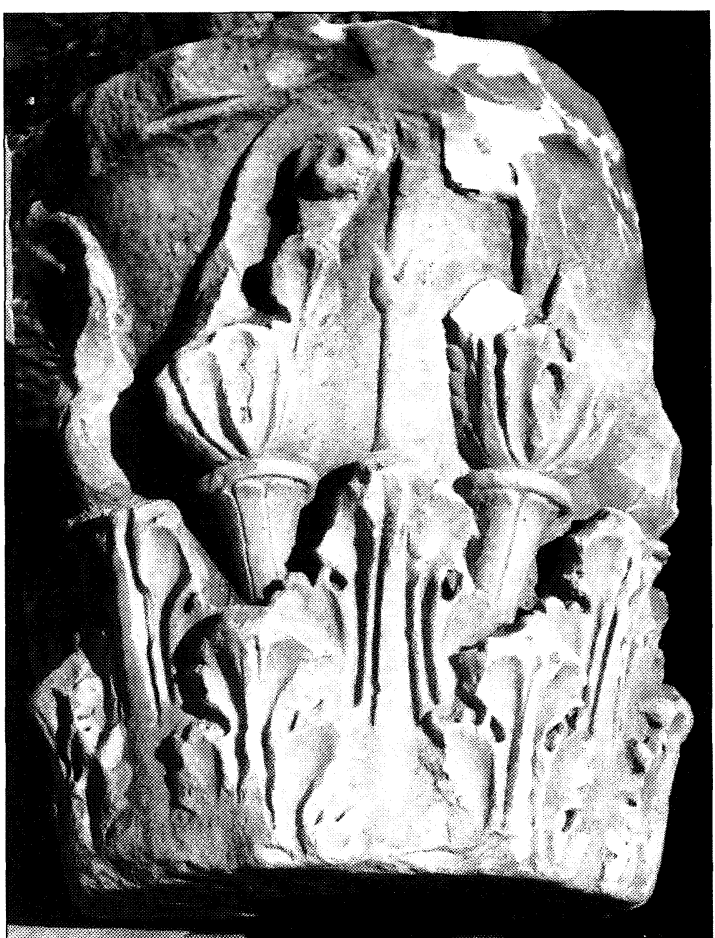

Fig. 26.-Capitel corintio del teatro.

toda seguridad procedente de Luni, Carrara). La plasticidad y naturalidad de la que hacen gala sus elementos, unido a las características zonas de sombra en forma de gota de agua y a las proporciones de los elementos que lo componen, hace que su cronología sea la del final del periodo augusteo o la inicial del principado de Tiberio ${ }^{52}$. El empleo del mármol de Carrara para su realización estaría indicando, según hipótesis de Pensabene ${ }^{53}$, un vínculo del emperador con el edificio donde estas piezas aparecen, idea ésta que debe ser tenida en cuenta como argumento de peso para avalar la idea de que este edificio formó parte de un proyecto imperial. La cercanía del lugar de aparición con la frons scaenae puede avalar la idea de que esta pieza adornase aquel ambiente. De igual modo no es posible aceptar que este capitel adornase la fachada exterior de la cavea porque para ello se requiere un capitel de columna adosada al muro, mientras que el que aquí comentamos adornaría una columna exenta.

${ }^{52}$ El estilo de estos capiteles es similar al del templo de Mars Ultor. Vid. J. Ganzert, Der Mars-Ultor Tempel auf dem Augustusforum in Rom, Mainz am Rhein 1996, 151 ss., láminas 65-68.

${ }_{53}$ P. Pensabene, "Classi sociali e programmi decorativi nelle province occidentali», XIV Congreso Internacional de Arqueología Clásica, Tarragona 1994, 298. 
Una interesante información nos es proporcionada por el lote de fustes presentes en la zona. Los dos más importantes aparecieron en el solar de la calle Rey Heredia. El primero de ellos, con un diámetro aproximado de $68 \mathrm{~cm}$., debió tener una altura cercana a los 4,7 metros. Tan importante como sus medidas es el material en que está hecho, el mármol verde antico ${ }^{54}$, cuyas canteras se localizan en Tesalia (Grecia). El segundo fragmento es de dimensiones más modestas (su diámetro es de 0,42 metros y su altura aproximada de 2,6 metros), pero el material también es de importación, el llamado marmor caristium, conocido también como mármol cipolli$n o{ }^{55}$. Dos fustes más completan el panorama de este elemento. Depositados en el patio del Museo, tienen unas dimensiones similares a los dos anteriores, estando elaborados en un mármol parecido a la caliza extraída de las canteras egabrenses. Las similares dimensiones avalan, a priori, su uso en una misma estructura, quizá la frons scaenae, aunque esta hipótesis debe ser corroborada.

Sólo se ha encontrado un arquitrabe cuya particular división en dos fasciae y el hecho de contar con la hoja inferior más desarrollada que la superior avalan una cronología augustea para su elaboración. La piedra local en que está labrada confirma el uso de la misma, de forma profusa, en el momento de la construcción del edificio. Su ubicación original es difícil de determinar habida cuenta que se encontró reaprovechada en un muro tardío.

Hemos dejado para el final el análisis de dos piezas sin lugar a dudas emblemáticas en la arquitectura romana y que encierran un significado muy concreto dentro del lenguaje de las formas a las que aquélla se remite. Nos referimos a un fragmento de clípeo y otro con guirnalda sobre los que hemos elaborado un estudio particularizado que exponemos a continuación.

Como elemento arquitectónico de gran importancia podemos reseñar un fragmento de clípeo. Aparecido en el año 1946 y desde entonces conservado en los fondos del Museo, este fragmento de clípeo ${ }^{56}$ resulta del mayor interés en el estudio de la decoración arquitectónica local. El clípeo en la arquitectura romana como elemento ornamental ocupa un lu-

${ }^{54}$ G. Borghini, Marmi antichi, Roma 1992, 292 s.; H Mielsch, Buntmarmore aus Rom im Antikenmuseum Berlin, Passau 1985, 63-64, lám. 20.

${ }_{55}$ Borghini, cit. (n. 54), 202; Mielsch, cit. (n. 54) 57

56 C. Márquez en D. Vaquerizo (coord.), Córdoba en tiempos de Séneca, Córdoba 1996, 94. Sobre otros tipos vid $E A A$ II voz Clipeate, immagini (Becatti). Adornando los frontones de los templos vid. M. Floriani, «Corona Civica e Clipeus Virtutis da Ostia» en Miscellanea archaeologica Tobias Dohrn dedicata, Roma 1982, 45 ss. gar destacado dentro de los signa que establecen un claro vínculo entre los edificios a los que pertenecen y el culto imperial. Su presencia se limita casi a los complejos forenses ${ }^{57}$, donde puede ocupar dos lugares: adornando los áticos de los pórticos ${ }^{58} \mathrm{o}$ bien decorando el podium del templo forense ${ }^{59}$

La pieza formaría parte de la decoración arquitectónica de un edificio (o complejo) ubicado en la terraza superior del teatro cordobés. No sería éste el primer caso conocido en Hispania, pues las excavaciones llevadas a cabo por R. Corzo en el teatro de Itálica ${ }^{60}$ sacaron, en un nivel de relleno, otro fragmento de clípeo. Si así fuera y la pieza cordobesa perteneciese a las inmediaciones del teatro, podría relacionarse la pieza con los fragmentos de altar con representación de guirnaldas.

En cuanto al significado de esta pieza, ha sido reiteradamente puesto en evidencia el vínculo existente entre clípeos y culto imperial ${ }^{61}$. Y no es menor el existente entre teatro y culto imperial, fenómeno que merece un estudio en profundidad pero que ya fue puesto de manifiesto por P. Gros ${ }^{62}$, quien ya avanzó la rapidez con la que algunos teatros hispanos entraron «... dans le cercle des monuments vorrées à l'exaltation des dynasties en place» ${ }^{63}$, grupo al que debe sumarse el teatro cordobés.

Otra pieza digna de ser reseñada es un fragmento de relieve con guirnalda ${ }^{64}$ (fig. 27) aparecido en las excavaciones realizadas en 1994. Tiene un pésimo estado de conservación debido a la corrosión del agua; el relieve se adorna con una guirnalda sostenida en su parte inferior por los extremos de dos ínfulas. La base se decora con un cimacio lésbico del tipo Bügelkymation. Sin lugar a dudas es esta pequeña franja la que mayor ayuda e información nos ha brindado; esta zona conserva los canales (que debieron ser profundos en origen) que separan el arranque del arco del estribo (Bügel) y dos ele-

57 El de Augusto fue el modelo de los Foros que luego se expandirán por algunas provincias de occidente.

${ }_{58}$ Así el modelo del Forum Augustum imitado en el pórtico del Foro de Mérida y en el pórtico del Foro Provincial de Tarraco. Vid. P. Zanker, cit. (n.15); J. L. de la Barrera, cit. (n. 15); P. Pensabene cit. (n 53).

${ }_{59}$ Ciertamente pueden reducirse los ejemplos de este tipo al templo de culto imperial de Avenches. Vid. M. Verzàr, Aventicum II. Un temple de culte impérial, Avenches 1977 fig. 8. Sobre el origen de esta decoración en el sur de la Galia y en las ciudades del norte del Adriático, ibidem, 34 ss.

60 Noticia recogida por Trillmich cit. (n. 23).

${ }^{61}$ P. Pensabene, cit (n.53) 94; M. Verzàr cit. (n. 59), 40.

62 P. Gros, «Théâtre et culte impérial» en P. Zanker, W. Trillmich (Hrgb.), Stadtbild und Ideologie, Madrid 1987, München 1990, 381 ss.

63 Ibidem, 389.

64 A partir de ahora lo denominaremos fragmento A. Placa de mármol blanco. Altura: $50 \mathrm{~cm}$; ancho: $29 \mathrm{~cm}$; grosor: $19 \mathrm{~cm} \mathrm{ca}$. 


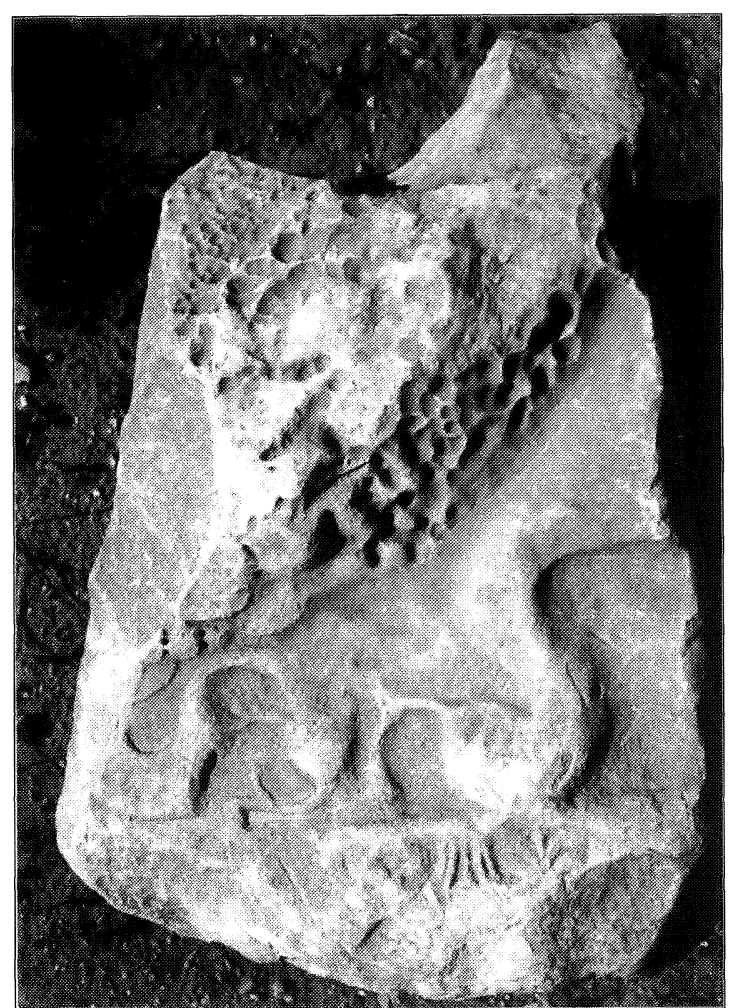

Fig. 27.-Fragmento de relieve con guirnalda procedente del teatro.

mentos distintos que adornaban su interior: una palmeta de cinco lóbulos y una pequeña flor de cuatro pétalos, ésta en el interior del otro estribo.

De este fragmento no se puede extraer más información que la facilitada por el peculiar modo de adornar los arquitos del Bügelkymation. Idéntico resulta el cimacio lésbico que corona un fragmento conservado en los fondos del Museo Arqueológico Provincial ${ }^{65}$ y cuyo esquema no se repite en ningún otro fragmento de la decoración arquitectónica de Córdoba (si bien el esquema Bügelkymation está presente en Córdoba en numerosos fragmentos, lo normal es que se decore con una lanceta o con hojas lanceoladas, como se puede ver en el arquitrabe del templo de la calle de Claudio Marcelo). Creemos, y en ello basamos el análisis de estas piezas, que ambos elementos formaron parte de un mismo relieve. En este fragmento B se observa el arranque de una guirnalda sostenida en su extremo por un elemento difícil de definir con exactitud. En su lado izquierdo se conserva el extremo de un ala que ocuparía todo o parte del campo existente encima de la guirnalda.

Es también el fragmento B el que conserva me-

${ }^{65}$ A partir de ahora, fragmento B. Procedencia desconocida. Mármol blanco. Altura: 35,5; ancho: $27 \mathrm{~cm}$; grosor: 16 cm ca. jor el Bügelkymation ${ }^{66}$, que analizamos a continuación a fin de obtener criterios seguros de datación. Las características de este modelo se resumen en:

- Sección cóncava de los arcos.

- Adorno vegetal en el espacio interior de los ar$\cos$.

- Entre los estribos, cálices con florecita u hoja en su centro.

Todas estas características son de época medioaugustea ${ }^{67}$ y los hallamos en edificios como el Arco de Augusto (19 a. de C.); orden inferior de la Basilica Aemilia (refección posterior al 14 a. de C.); Templo de Cástor ${ }^{68}$. Pero del mismo modo, otros aspectos apuntan a un periodo julio-claudio tardío como momento en que se labró la pieza:

- Toques de trépano que como puntos oscuros se colocan a ambos lados del coronamiento del estribo.

- Presencia de un pequeño pedúnculo que une los motivos vegetales que rellenan el arquito (palmetas y flores) con el lóbulo de coronamiento (en época augustea el contacto es directo mientras que en el periodo flavio se realiza a través de un desarrollado pedúnculo ${ }^{69}$ ).

Los mismos toques de trépano aparecen en el arco de Claudio y en otro edificio contemporáneo a aquél ${ }^{70}$. La segunda característica pone de manifiesto la importancia del periodo claudio en el que ya aparecen algunas novedosas ideas que son tomadas y desarrolladas por el arte del periodo flavio.

Así pues sería el principado de Claudio el momento en que, a juzgar por el análisis estilístico, se labraría esta pieza; una vez más se pone de manifiesto el influjo del periodo augusteo en el desarrollo de la decoración arquitectónica romana altoimperial en las provincias. No es ajeno a este influjo el motivo de la palmeta como elemento que rellena los estribos; palmetas idénticas a las de la pieza $\mathrm{B}$ manifiestan, en estos y otros fragmentos cordobeses, una clara proximidad a elementos utilizados en época augustea del repertorio neoático como los candelabros ${ }^{71} \mathrm{o}$ se encuentran en arquitrabes augusteos de otras ciudades como Cesarea de Mauritania ${ }^{72}$.

${ }^{66}$ Sobre el tipo vid. Ch. Leon, Die Bauornamentik des Traiansforums, Wien 1971, p. 245 ss.; J. Ganzert, «Augusteische Kymaformen. Eine Leitform der Bauornamentik», en Kaiser Augustus und die verlorene Republik, Ausstellung Berlin 1988, p. 116 ss.

${ }^{67}$ Leon, cit. (n. 66), 271.

68 Ibidem, 251.

69 Véanse los ejemplos flavios en ibidem, lám. 113.

70 Ibidem, 254, lám. 112, 3-4.

71 H. U. Cain, Römische Marmorkandelaber, Mainz am Rhein 1985, n. 125, p. 197, lám. 27,1.

72 P. Pensabene, «La decorazione architettonica di Cherchel: cornici, architravi, soffiti, basi e pilastri» Römische Mitteilungen Erg. 25, n. 167, p. 137, lám. 42,3. 
¿Qué función cabría dar a estos fragmentos? Tres son las posibilidades que barajamos:

1. Friso. Se conocen frisos con guirnaldas desde época republicana en edificios públicos y funerarios ${ }^{73}$ pasando por edificios augusteos (como el orden interno del templo de Mars Ultor ${ }^{74}$ ). En Hispania serían los frisos de Tarragona los paralelos más cercanos ${ }^{75}$. Las medidas de nuestra pieza completa (vid. infra) y el hecho de tratarse de una placa y no de un bloque no son característicos de un friso. A ello cabría añadir que la presencia del cima inferior invertido restaría probabilidades a una hipotética función como friso si bien se conocen algunos ejemplos con esta peculiaridad.

2. Relieve ornamental-

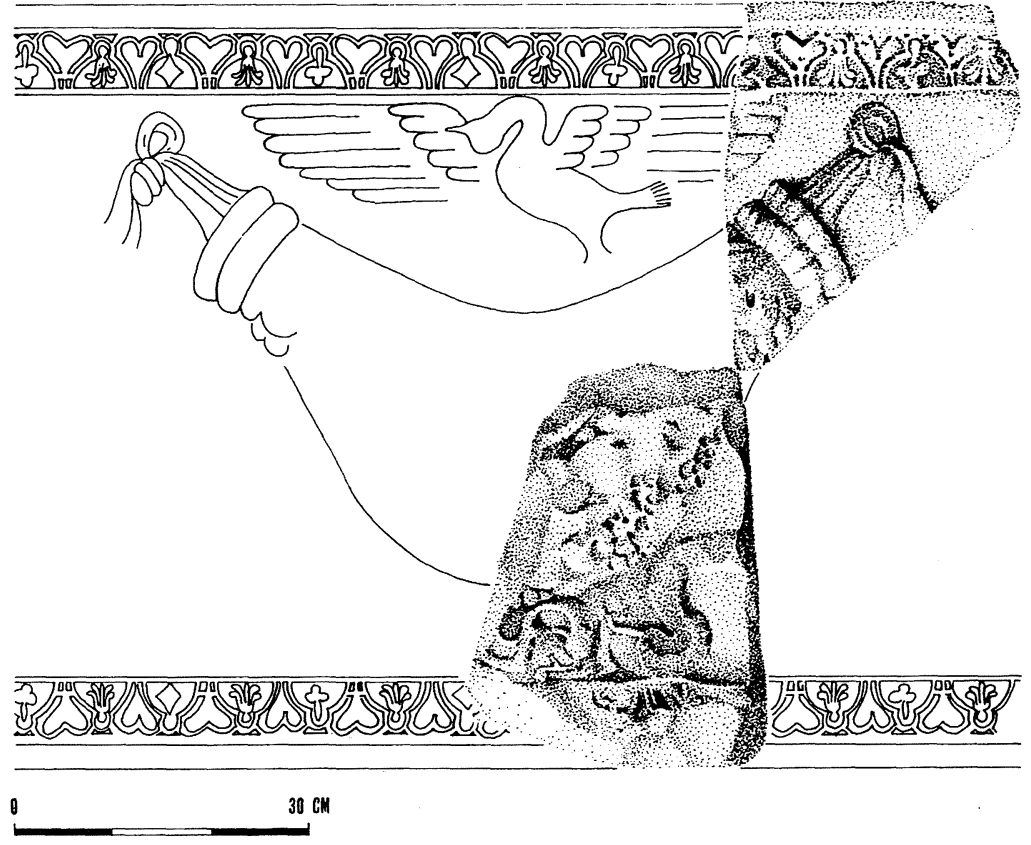

Fig. 28.--Restitución hipotética del relieve con guirnalda. (Dibujo M. Carmona.) funcional: en algunas ciudades se han encontrado bloques con guirnaldas adornando complejos a modo de balaustradas ${ }^{76}$. A este mismo modelo responde la presencia de cabezas de medusa y de Júpiter Amón enmarcados en clípeos ${ }^{77}$.

3. Altar: es necesario advertir que esta hipotética función no estaría vinculada con la scaenae frons o con la orchestra del edificio teatral aquí estudiado por una sencilla razón topográfica. Los fragmentos del relieve se hallaron en la zona del pórtico in summa cavea, de ahí que deba adscribirse a esa zona o bien a la terraza superior.

La interpretación de la pieza requeriría una restitución de la totalidad del panel al que perteneciese, cuestión ésta que se intentará resolver a continuación. Como se observa en la figura 28 se ha intentado unir los fragmentos A y B a través de la curvatura adoptada por la guirnalda y, elemento fundamental, dejando el espacio suficiente en el hueco superior para colocar allí el animal cuya ala se aprecia en el fragmento B (sobre esto, vid. infra). De esta forma, el panel tendría una altura aproximada de $75 \mathrm{~cm}$.

73 Vid. G. Cavalieri, La decorazione architettonica di Aquileia, Trieste, Pola.I, nota 1 en p. 74 para el desarrollo de este motivo.

74 Kockel, cit. (n. 18), 435, fig. 17, lám. 115-1, 5 y 6

75 Pensabene cit. (n. 53), 83 ss

76 Verzàr, cit. (n. 59), 42, fig. 9, nota 90.

77 Un fragmento de clípeo depositado en el Museo Arqueológico Provincial de Córdoba con el número de registro 9.327 procede de este mismo solar.
Queda por explicar la elección del cisne como animal al que perteneciesen las alas. La posición totalmente horizontal de las plumas conservadas en la pieza $\mathrm{B}$ elimina la presencia de una victoria o de un erote, amén del escaso espacio disponible; excluida tal posibilidad, sólo podría estar representado un águila o un cisne; una detallada búsqueda entre los relieves del período claudio hizo que nos decidiéramos por el cisne, muy representado en urnas funerarias de este período, de una de las cuales hemos tomado el modelo ${ }^{78}$. Además de los numerosos ejemplos de cisnes ocupando el espacio libre por encima de la guirnalda en las urnas funerarias de época claudia, la presencia del símbolo de Apolo en relación directa con la guirnalda estaría rememorando el Ara Pacis Augustea donde, sin embargo, ambos motivos no aparecen juntos ${ }^{79}$. Estaríamos, pues, ante un modelo derivado del Ara Pacis donde se ha producido un sincretismo en sus elementos;

${ }^{78}$ F. Sinn, Stadtrömische Marmorurnen, Mainz am Rhein 1987, nn. 114-115, p. 120, lám. 28 a-c.

79 E. Simon, Ara Pacis Augustae, Tübingen s.d., p. 13 s. lám. 7 s. Sobre el cisne vid. R.E. 2-a, voz Schwan (Gassen). Sobre el significado del cisne en el Ara Pacis vid. H. P. L'Orange, "Ara Pacis Augustae. La zona floreale» Acta ad archaeologiam et artium historiam pertinentia 1, 1962, 12 ss.; sobre el cisne en las urnas funerarias, F. Sinn afirma que recuerda a los cisnes que coronan los frisos de acantos del Ara Pacis, si bien no es seguro que tengan este significado en las urnas; vid. Sinn, cit. (n. 78), 59. 
creemos, efectivamente, que los fragmentos cordobeses forman parte de un monumento (¿Altar?) que sigue el modelo del Ara Pacis, tal como se ha atestiguado en varias ciudades del Imperio ${ }^{80}$ y que simboliza, en el caso de ser encargado por la ciudad (particulares, colegios) la adhesión de estos grupos a la ideología imperante o bien la manifestación de su agradecimiento por favores recibidos. Caso distinto sería si fuese encargado por el poder central pues habría que ver en ello un ejemplo más de propaganda imperial ${ }^{81}$.

Si este altar formaba parte de la summa cavea del teatro (sacellum in summa cavea) o de un edificio situado en la terraza superior del complejo, es algo que no puede ser evaluado hasta realizar nuevas investigaciones en la zona.

\subsection{Materiales procedentes de la frons scaenae}

En los fondos del Museo Arqueológico se guardan unas piezas procedentes de la calle Marqués del Villar esquina a la Plaza de Jerónimo Páez, o sea, del lugar supuestamente ocupado por la frons scaenae del teatro. Esta intervención se realizó en 1979 y los restos se hallaron a $6,7 \mathrm{~m}$ de profundidad respecto a la cota de suelo actual, lo que proporciona un dato de sumo interés para conocer la topografía antigua de la zona y la profundidad, aproximada, donde se localizan las estructuras. El numeroso lote ayuda, pues, a conocer no sólo el ornato de la escena, sino que también puede aportar datos sobre las medidas de sus elementos y, además, sobre su cronología.

Comenzamos el análisis procedente de esta zona haciendo referencia a las basas; de los tres fragmentos conservados, dos de ellos son basas áticas sin plinto (fig. 29), cuya ausencia nos ayuda a conocer su cronología que debe ser centrada en el periodo de Augusto ${ }^{82}$. A partir de este periodo todas las basas (al menos todas aquellas que se emplean en la edilicia pública) cuentan con este elemento de apoyo.

Tres han sido también los fragmentos de fuste procedentes de este sector. De dimensiones semejantes (el cálculo para las piezas completas señala una altura de 3 metros circa) varían, no obstante, en su ornamentación, siendo el primero de ellos liso, el segundo de canales helicoidales y el tercero acanalado. Otra característica que los unifica es el mármol pavonazzetto en que están elaborados.

${ }^{80}$ E. Ghisellini, Römische Mitteilungen 95, 1988, 187 ss.; en Mérida contamos con un interesante modelo; vid. W. Trillmich, $M M$ 27, 1986, 279 ss.

${ }^{81}$ Ghisellini, cit. (n. 80), 202 ss.

82 Márquez, cit. (n. 7), 83 ss.

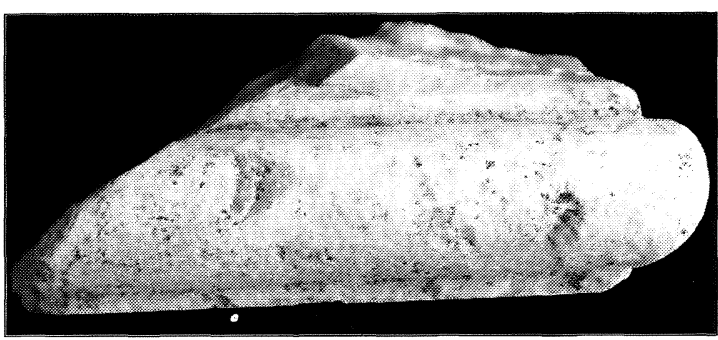

Fig. 29.-Fragmento de basa con plinto.

Llegamos ahora al capítulo dedicado a capiteles que, al igual que en el apartado anterior, ofrece un particular interés. De los cuatro fragmentos localizados (siempre pertenecientes, a priori, a la frons scaenae), destaca un ábaco liso cuya altura, superior a $10 \mathrm{~cm}$ (la pieza está fracturada), pertenecería a un capitel que mediría más de un metro de altura, parangonable en lo que a dimensiones se refiere a los capiteles del templo de Claudio Marcelo. Otro fragmento procedente de este lugar pertenece a un capitel corintio-asiático. Tiene $16 \mathrm{~cm}$ de altura y de él sólo se conserva una hoja. El tipo corintio asiático está muy extendido en el periodo romano tardío, caracterizado por unas hojitas puntiagudas que se tocan entre sí creando zonas de sombra en forma de figuras geométricas. Por su semejanza con piezas ostienses del siglo IV podemos establecer en ese momento su cronología. Es destacable, además, que tenga características muy parecidas a otros capiteles tardíos hallados en la península ibérica. Su empleo en este edificio manifiesta una refectio del edificio escénico en época constantiniana, fenómeno que se observa en ciudades como Itálica o Ferento.

\subsection{Material de probable pertenencia al teatro}

De entre el numeroso material depositado en los fondos del Museo Arqueológico y en colecciones privadas, queremos destacar algunas piezas cuyas características avalan su hipotética adscripción al edificio aquí analizado. La primera de ellas es un fragmento de balteus, es decir, la barrera que separa la orchestra de las gradas. Su particular molduración y la curvatura que adopta son argumentos que avalan esta función si bien se desconoce el lugar de procedencia de la pieza.

La segunda pieza tiene unas características muy distintas. Se trata de un bloque de mármol donde se ha labrado una máscara trágica (fig. 30) ${ }^{83}$. La cara,

${ }^{83}$ Conservada en el Museo Arqueológico Provincial de Córdoba con el número de registro 27.107 procede de la calle Cardenal Herrero, junto a la Mezquita. Mármol blanco. Altura: $48 \mathrm{~cm}$; ancho: $35 \mathrm{~cm}$. 


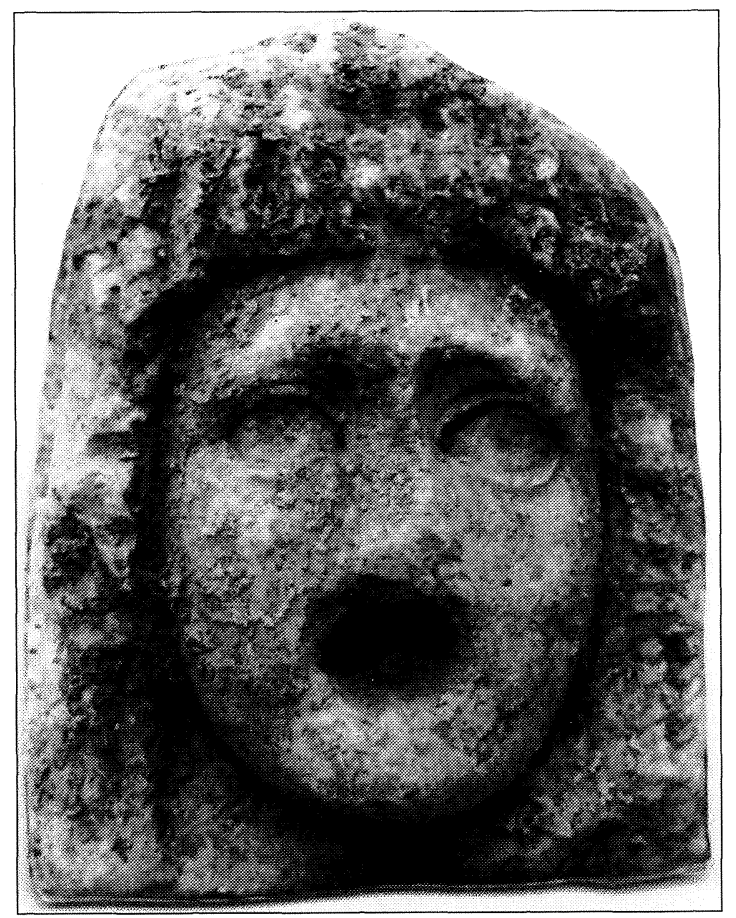

Fig. 30.-Máscara trágica del teatro.

de marcada tendencia ovalada, tiene como marco el cabello formado por bucles de rizos paralelos que dejan sin cubrir la frente pero que ocultan las orejas. La barbilla está sin definir; la boca, hueca, y los grandes ojos están muy señalados por unos párpados perfectamente diferenciados y un orificio en el iris. Detalle a destacar es que la parte superior de la máscara sobresale respecto a la inferior, lo que indicaría que su posición original estaría a mayor altura que la normal de un individuo. Parece fuera de toda duda la adscripción de un elemento de estas características a un edificio de espectáculos pues todos los paralelos hallados inciden en esa relación. El ejemplo por antonomasia lo representa el teatro de Marcelo ${ }^{84}$ en Roma con máscaras marmóreas que adornan las claves de los arcos y que fue el modelo de otros edificios de la península itálica y del sur de la Galia ${ }^{85}$. La forma del bloque donde se labró la máscara induce a

${ }^{84}$ M. Fuchs, Untersuchungen zur Ausstattung römischer Theater in Italia und den Westprovinzen des Imperium Romanum, Mainz am Rhein 1987, p. 14, lámina 1; P. Ciancio Rossetto, Bulletino Comunale 88 (1982-83), p. 7 ss.; eadem, «Le maschere del teatro di Marcello a Roma», Spectacula II. Le théâtre antique et ses spectacles, Actes Colloque Lattes (1989), p. 187 ss.

${ }_{85}$ Así, en el anfiteatro campano de Sta. María Capua Vetere y el teatro de Benevento. Vid. G. Pesce, I rilievi dell'anfiteatro campano, Roma 1941; A. de Franciscis, Bulletino d'Arte 1950, p. 153 ss.; R. Pane, NSc 1924, p. 516; Ciancio, Bulletino Comunale 88 (1982-83), p. 18, lám. VIII-2. creer que su función sería la de clave de uno de los arcos por los que se accedía al edificio teatral ${ }^{86}$. Además de estos ejemplos donde se documenta tanto la pieza como su edificio de origen, el número de máscaras procedentes de Roma y su entorno habla del frecuente uso que de ellas se hacía ${ }^{87}$.

Una segura definición del tipo representado se ve dificultada por la erosionada superficie de la pieza, sobre todo en su extremo superior; es seguro, sin embargo, la presencia de un bajo oncos que deja libre la frente, ocultando las orejas en los laterales por los rizos que caen hasta la altura de la barbilla. Tiene esta pieza muchas concomitancias con una máscara trágica femenina perteneciente, con toda probabilidad, al teatro de Marcelo ${ }^{88}$ identificada como la koúrimos parthenos ${ }^{89}$; en cualquier caso parece segura su no inclusión como máscara trágica masculina ${ }^{90}$. También mantiene un gran parecido con una máscara trágica que encarna a una heroína hallada en Tralles ${ }^{91}$.

No resulta menos fácil intentar un acercamiento a su cronología; para ello acudiremos a algunos paralelos hasta ahora vistos y a cuestiones relacionadas con la técnica empleada en su realización. De las piezas arriba enumeradas, el ejemplar cordobés guarda una mayor afinidad con los ejemplares del Teatro de Marcelo, dedicado a la memoria del sobrino de Augusto en el año 13 o bien en el 11 a. de C. ${ }^{92}$. Muy cercana en el tiempo se encuentra la más-

${ }_{86}$ La posible adscripción de este elemento como parte de la frons scaenae habría que descartarla por razones de funcionalidad. Las máscaras conocidas de Ostia adornan los frentes de las ménsulas de su escena que sostendrían columnas; caso muy distinto es el de la pieza cordobesa. $\mathrm{C}$ fr. $\mathrm{G}$. Calza, Scavi di Ostia. I. Topografia generale, Roma 1953, p. 116 ss.; H. Schaal Ostia. Der Welthaffen Roms, Bremen 1957, p. 56; R. Calza, E. Nash, Ostia, Firenze 1959, p. 64, lám. 87; A. Neppi Modona, Gli edifici teatrali greci e romani, Firenze 1961, lám. VI-b. P. Rodríguez Oliva, «El símbolo de Melpómene. Teatro y muerte en la España romana» en Estudios dedicados a Alberto Balil in memoriam, Málaga 1993, 51, lám. II,2.

87 De Roma y sus alrededores proceden, además, las siguientes: M. Cagiano de Azevedo, Le Antichità di Villa Medici, Roma 1951, n. 43, p. 55, lám. XI-14; F. Matz, F. von Duhn, Antike Bildwerke in Rom, Leipzig 1881, nn. 1653, 1653-a y 1654; B. Ashmole, A catalogue of the ancient marbles at Ince Blundell Hall, Oxford 1929, nn. 130-136, p. 56 ss., lám 46.

88 Ciancio, Bulletino Comunale 88 (1982-83), p. 48, lám. LIX, 2 .

${ }^{89}$ Pollux, Onomasticon IV, 141.

90 Sobre tipos de máscaras $R E$ voz Maske (Bieber).

91 M. Bieber, The history of the Greek and Roman theater. Princeton 1961, p. 243, fig. 801. Ya en las terracotas del siglo III a. de C. podemos encontrar un modelo con rostro ovalado, frente despejada y onkos enmarcando el rostro. Vid. L. Bernabò Brea, Menandro e il teatro greco nelle terracotte liparesi, Genova 1981, G-3, p. 121.

${ }_{92}$ Cass. Dio., LIV, 26, I; Pl. N.H. VIII, 65. 
cara conservada en el Museo de Barcelona habida cuenta del idéntico tratamiento dado a los rizos del oncos. Los ejemplares del anfiteatro campano y del teatro de Benevento, ya del siglo II, parecen mostrar un mayor gusto por contrastes de claroscuro. Para conocer la cronología resulta fundamental comprobar de qué modo ha sido labrada la pieza; en este sentido cabe destacar la utilización del cinceles de variadas puntas, mientras que no se percibe la presencia del trépano salvo, quizá, para horadar el hueco de la boca. Tan significativa ausencia remite para los elementos arquitectónicos de Colonia Patricia a un periodo no posterior al principado de Claudio.

A modo de conclusión, habría que destacar la presencia en Córdoba de un elemento ornamental típicamente itálico como adorno de las claves de los arcos de entrada. El tratarse de una máscara remite indudablemente a la ornamentación del Teatro de Marcelo en Roma, que no sería seguramente ajeno al influjo del mundo griego ejercido a través del modelo representado por los frisos de máscaras de los teatros de Pérgamo y Atenas ${ }^{93}$. La máscara se fecharía por las razones ya esgrimidas, en un momento anterior a finales del periodo julio-claudio.

\subsection{Cronología del teatro}

Los testimonios proporcionados por algunas piezas ya vistas apuntan al augusteo como momento en que comienza a decorarse este edificio. Ello confirmaría que sería el primer momento imperial el que ve surgir este edificio y los complejos edilicios con él relacionados, que se verían adornados acto seguido de su construcción.

Periodo augusteo: Los elementos más antiguos fácilmente fechables a través del método estilísticocomparativo son el capitel de la lámina 26 y la basa de la lámina 29. El primero de ellos, a raíz de su estilo de clara impronta augustea, tiene influjos estilísticos de piezas elaboradas en la capital, Roma (son los capiteles del templo del Mars Ultor), siempre del periodo augusteo. A este mismo periodo remiten las características de las basas que coinciden en no poseer plinto, elemento que se generaliza sólo a partir del principado de Augusto.

Periodo julio-claudio: La mayor parte de los elementos ornamentales aquí analizados se pueden fechar en la primera mitad del siglo I de C., es decir, una vez que la estructura del edificio escénico y de las terrazas laterales ha finalizado. Así podemos destacar el relieve con guirnalda que adornaría un

\footnotetext{
${ }^{93}$ Ciancio, cit. (n. 88), 17, notas 80 y 81 .
}

sacellum. Es, por consiguiente, el julio-claudio el momento en que se realiza un mayor esfuerzo por ornamentar el complejo edilicio.

Siglo II: Algunas piezas, sobre todo escultóricas (que son objeto de análisis en otro estudio), pueden datarse en este momento como son dos estatuasfuente y una escultura que representa a una Nike. Arquitectónicamente apenas se constatan refectiones en este periodo, por lo cual podemos afirmar que el teatro siguió su vida sin grandes novedades durante este siglo y el siguiente.

Siglo Iv: A este momento tardío corresponde el capitel corintio asiático de la frons scaenae. Su presencia sugiere una refectio del edificio escénico en el siglo Iv, fenómeno que se ve corroborado en otros teatros como el de Itálica y el de Ferento ${ }^{94}$.

Tan interesante como el edificio teatral en sí y los elementos que lo constituyen, se nos presenta el entorno más inmediato del mismo; el análisis del relieve con guirnalda, con toda probabilidad coetáneo a la edificación del conjunto lúdico, sugiere la presencia de un sacellum in summa cavea, con claras referencias al teatro de Pompeyo en Roma; el relieve con figura de Victoria emplaza al momento tardoflavio-trajaneo para su realización; al tratarse de una sola figura incompleta no podemos indicar la función exacta de esta pieza. Por el lugar de hallazgo, al exterior del teatro y en una de las terrazas que lo flanquean, formaría parte de un monumento conmemorativo, importante a juzgar por las dimensiones de la pieza.

La conclusión de nuestro trabajo, siempre a expensas de nuevas excavaciones, es que el modelo de edificio escénico elegido es el teatro de Marcelo en Roma, al que pretende sin lugar a dudas emular ya sea en las dimensiones del proyecto, ya en detalles ornamentales como la decoración con el orden dórico toscano, arcadas de ingreso al edificio y máscaras en las claves de sus arcos. El análisis estilístico de las piezas nos muestra un primer período constructivo fechado en época julio-claudia en el que se insertan elementos ornamentales como la máscara o el relieve con guirnalda, esta última de mediados del principado de Claudio. Sería a partir de este momento también cuando se introduzca la ornamentación a través de los mármoles de color, tal como se atestigua en gran cantidad de edificios teatrales.

Queda reiterada la importancia urbanística dada al entorno del teatro. La impronta helenística observable en el aterrazamiento y en la misma presencia de un sacellum, permite intuir la envergadura de un complejo situado en la cota superior de la colina

\footnotetext{
${ }_{94}$ P. Pensabene, Il teatro romano di Ferento, Roma 1989.
} 
donde se asienta el teatro, los Altos de Santa Ana. En este entorno monumental se imbrica el relieve trajaneo de la Victoria, importante documento para observar una continuidad en la zona.

\section{Puertas urbanas}

\subsection{Puerta de Almodóvar (Figura 1, n 7)}

Directamente vinculada con las murallas augusteas, que delimitan el nuevo espacio urbano, se encuadra la pieza que comentamos a continuación. Se trata de la mitad inferior de un capitel corintio de pilastra (fig. 31) labrado en una de sus caras ${ }^{95}$. Las dimensiones de la pieza completa (el capitel se elaboraría en dos bloques de idénticas dimensiones) dan una altura total de $88 \mathrm{~cm}$ y hacen que se descarte su adscripción a un monumento funerario. Tiene una talla muy cuidada, lo que, unido al hecho de labrarse en dos bloques y a sus propias dimensiones, señalaría la ubicación de la pieza en un edificio de notables dimensiones, con seguridad de carácter público. Estilísticamente se puede encuadrar esta pieza con ejemplares augusteos y julio-claudios, como pone de manifiesto su proximidad al capitel de la Casa de las Antas de Glanum ${ }^{96}$. Esta impronta augustea está en sincronía con la erección de la muralla sur; sus nuevos lienzos precisan algunos vanos de acceso a la nueva zona urbanizada y es en esta función donde nuestra pieza puede tener un lógico anclaje: creemos que el bloque ahora analizado formó parte del programa ornamental que rodeó una puerta abierta en esta zona, cuya continuación en el tiempo llega hasta hoy.

Las especiales características del capitel al labrarse en dos bloques puede sernos de gran utilidad a la hora de un intento de reconstrucción del monumento al que perteneció. En época augustea es frecuente labrar los capiteles en dos bloques ${ }^{97}$ por razones de técnicas de manipulación y de transporte. En particular, los capiteles como el ejemplo aquí estudiado se labran a menudo en dos bloques porque cada uno de ellos corresponde a la altura exacta de una hilada de sillares ${ }^{98}$. A partir de este dato y

${ }_{95}$ La pieza apareció en un solar aledaño a la actual Puerta de Almodóvar, extramuros de la ciudad. Es de mármol blanco de grano medio. Su altura es de $44 \mathrm{~cm}$; su anchura es de $95 \mathrm{~cm}$ y su grosor es de $44 \mathrm{~cm}$.

96 W. D. Heilmeyer, cit. (n. 21), 111 y ss., lám. 7,4

${ }^{97}$ D. E. Strong; J. B. Ward Perkins, «The Temple of Castor in the Forum Romanum» Papers of the British School at Rome 30, 1962, 20 ss.

98 R. Amy, P. Gros, La Maison Carrée de Nîmes, Paris 1979, nota 167 en página 138.

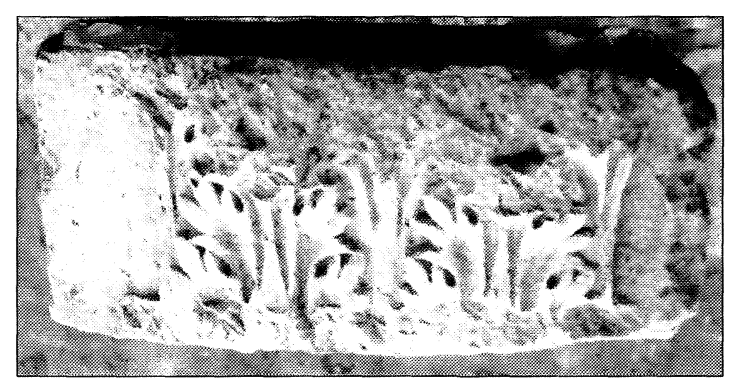

Fig. 31.-Fragmento de capitel de pilastra.

de la confrontación con otros edificios de similares características ${ }^{99}$ hemos intentado hacer un ensayo de restitución ${ }^{100}$.

¿Qué fue lo que motivó la construcción de una puerta en forma de arco honorífico? La respuesta viene dada por las claras connotaciones propagandísticas que en época augustea se dan. La ampliación al sur de la ciudad requería, como ya vimos antes, la realización de una cinta muraria que diferenciase claramente el interior y el exterior de la colonia. Se trata, en definitiva, de subrayar la imagen urbana a través de un monumento que sirve de punto de ingreso en la misma ${ }^{101}$, monumento inserto en unas murallas que separan el territorio del espacio urbano. ¿Y de qué mejor forma se puede construir una puerta cargada de toda esta simbología sino acercándola visual y formalmente a un arco honorífico? ${ }^{102}$. Queda de manifiesto que ya en época augustea el carácter defensivo de la

${ }^{99}$ En especial el arco de Rímini. Cf. G. A. Mansuelli, $I l$ monumento augusteo del 27 a.C., Bologna 1960; G. Traversari, L'Arco dei Sergi, Padova 1971; G. Tosi, L'Arco dei Gavi, Roma 1983; S. de Maria, «La porta augustea di Rimini nel quadro degli archi commemorativi coevi. Dati strutturali» en AA.VV. Studio sull'arco onorario romano. Studia Archaeologica 21, 1979, 73 ss. Se documentan en Bérgamo la evergesía de Crispus y su esposa Sedata construyendo una puerta en los siglos 1 o II de C. Vid. R. Poggiani, Bergamo dalle origini all'alto medioevo, Mantova 1986, 68.

100 C. Márquez, La decoración arquitectónica de Colonia Patricia. Una aproximación a la arquitectura y urbanismo de la Córdoba romana, Córdoba 1998, 192 ss.

101 D. Scagliarino, «La situazione urbanistica degli archi onorari nella prima età imperiale» en AAVV, Studio sull'arco onorario romano, Studia archaeologica 21, Roma 1979, 38. Umberto Ciotti, «Carsulae» en A. Violatti (ed.), San Gemini e Carsulae, Milano-Roma s.d., p. 31; idem, EAA voz Spello; U. Tarchi, «Rilievi e ricostruzionidi monumenti romani dell'Umbria», Bulletino Comunale LXIX, 1941, p. 35 ss; G. Lugli «Porte di città antiche ad ordini di archi sovrapposti» Archaeologia Classica I, 1949, p. 153.

102 De forma clara y contundente escribe de Maria: «Talora questi archi augustei d'Italia assumono la funziones di porta urbica nella cinta muraria, in quel clima di rinovamento che caratteriza ampiamente l'architettura pubblica delle città della penisola in questo periodo». EAA $2^{\circ}, 1994$, supp. voz Arco (S. de Maria). 
muralla ha dejado de tener sentido en muchas zonas ${ }^{103}$.

El carácter público de una ingente empresa como fuera la de la construcción de los nuevos lienzos de murallas y sus puertas, avalan la calidad, dimensiones y material con el que están hechos la pieza aquí comentada ${ }^{104}$.

\section{Monumentos funerarios}

Aunque han sido escasos los fragmentos asignados a edificios funerarios por su lugar de hallazgo, su particular forma nos permite trazar un esbozo de la imagen que en su día tuvieron. Diversos tipos pueden, de esta forma, destacarse:

\subsection{Túmulos}

En el año 1994 se desarrollaron unas excavaciones en el Paseo de la Victoria cuyo objetivo era el de conocer la entidad de un monumento aparecido en algunos sondeos realizados con anterioridad. $\mathrm{Al}$ margen de algunos edificios domésticos con una rica decoración musiva hallados al mismo tiempo, nuestra atención se va a centrar en el único edificio con elementos seguros de decoración arquitectónica. Se trata de un mausoleo circular (figura $1, \mathrm{n}^{\circ} 8$ ) de $13,5 \mathrm{~m}$ de diámetro aproximadamente ${ }^{105}$. De segura adscripción al edificio son dos elementos distintos aparecidos en la campaña mencionada:

a: basamento de zócalo (fig. 32). Amén de varios fragmentos aparecidos in situ rodeando el tambor del monumento, se hallaron otros en sus alrededores. Se compone de un filete que corona una escocia y que está separada de un caveto a través de otro filete; en su base, un plinto. Está hecho en caliza micrítica gris de la formación Pedroche del Cámbrico cordobés, conocida vulgarmente como piedra de

${ }^{103}$ El caso emblemático es Rímini, cuya puerta-arco se construye con seguridad en el 27 a. de C. y cuyas medidas le impiden tener un cierre.

104 Interesante resulta observar que los tres actos evergéticos vinculados con puertas reseñados por E. Melchor en la Bética se llevan a cabo en época republicana y augustea. Vid. E. Melchor, El mecenazgo cívico en la Bética. La contribución de los evergetas a la vida municipal, Córdoba 1994, pp. 153 y 156.

105 Agradezco a los directores de dicha intervención, Dr. J. F. Murillo, de la Gerencia de Urbanismo del Ayuntamiento de Córdoba, y Dr. J. R. Carrillo, de la Universidad de Córdoba, la amable invitación para estudiar los elementos ornamentales de este edificio. Una publicación monográfica sobre el monumento servirá para analizar detenidamente todos los aspectos relacionados con el edificio y su excavación. A ella me remito para las cuestiones referidas a tipología del edificio.

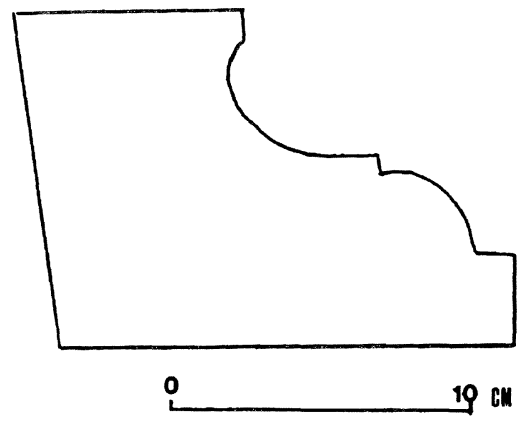

Fig. 32.-Zócalo del túmulo funerario del Paseo de la Victoria.

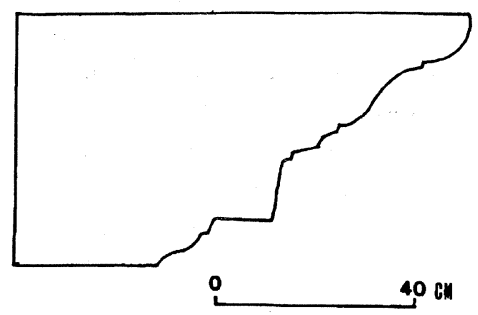

Fig. 33.-Sección de la cornisa del túmulo funerario.

mina. Tiene $29 \mathrm{~cm}$ de anchura y $40 \mathrm{~cm}$ de profundidad, variando sustancialmente su anchura.

b: Cornisas de mármol blanco (fig. 33). El desarrollo de sus molduras es el siguiente: óvolo, listel, cima recta, listel, óvolo, listel, filete, listel y cima reversa. Su altura es de $37 \mathrm{~cm}$, la base tiene $77 \mathrm{~cm}$ de profundidad y la zona superior, $107 \mathrm{~cm}$. La anchura, al igual que el basamento, es variable.

La molduración de la base del tambor cilíndrico tiene un desarrollo que arranca en la etapa mediorrepublicana; entonces conocemos ejemplos en santuarios centroitálicos ${ }^{106}$ donde aparecen todas las molduras de la pieza cordobesa a excepción del filete central. La datación de estos edificios itálicos coincide con la del templo republicano de Ampurias ${ }^{107}$ así como también es idéntica la molduración de las basas del podium.

En época augustea nos encontramos el mismo desarrollo en basas de Glanum, ciudad que cuenta con tres ejemplos que abarcan todo el periodo augusteo: los denominados «templos geminados» ${ }^{108}$ fechados en el año 20 a. de C. ${ }^{109}$; el mau-

106 A. La Regina, «Il Sannio» en P. Zanker (ed.), Hellenismus in Mittelitalien I, Kolloquium Göttingen (1974), 1976, p. 219 ss., figs. XI y XIII.

107 J. Aquilué, cit. (n. 41), fig. 15 en p. 51. El podio del templo se data en los años finales del siglo II a. de C.

${ }_{108} \mathrm{P}$. Gros, Revue archéologique de Narbonnaise XIV 1981, p. 125 ss., fig. 50.

109 Ibidem, p. 152. 
soleo ${ }^{110} \mathrm{y}$ finalmente el arco de Glanum, monumento fechado en las postrimerías del principado de Augusto o en los inicios del de Tiberio ${ }^{111}$, del que nos interesa destacar la separación de la cima recta (que hasta entonces se había mantenido inalterable) a través de un listel. Se trata, por primera vez, de una molduración idéntica a la que ofrece la pieza cordobesa.

Mérida, Barcelona y Carteia ofrecen ejemplos hispanos con similar molduración a lo que venimos viendo hasta ahora; así en Mérida se halló la moldura del podio de un edificio en la calle J.R. Mélida esquina a Sagasta. Es de granito revestido de estuco y De la Barrera lo fecha en el periodo augusteo ${ }^{112}$. En Barcelona aparece adornando el emblemático templo de Barcino ${ }^{113}$ fechado por Barrera aproximadamente en los años 30 a. de C. ${ }^{114}$; finalmente en Carteia también se encuentra adornando el templo de fines del siglo I a. de C. ${ }^{115}$. Tendrá continuación este particular esquema decorativo durante el periodo flavio, después del cual no hemos hallado más paralelos. En Lusitania se conserva el podio de un templo, fechado por Alarcão en época flavia (aunque no se da como segura) y que repite las mismas molduras ${ }^{116}$. A la segunda mitad del siglo pertenece el sepulcro circular de Pompeya, que ha sido identificado probablemente como de C. Fabius Secundus ${ }^{117}$ y en cuya base se observa un desarrollo algo más estilizado y alargado del caveto.

Haciendo un resumen de lo hasta ahora visto, podemos comprobar que la cima reversa, como moldura que adorna los basamentos de los podios, tiene un origen mediorrepublicano en el mundo itálico y que se expande por toda la península ibérica desde inicios del siglo I a. de Cristo (Ampurias) hasta el periodo augusteo (Mérida, Barcelona, Carteya). Pero será en el periodo augusteo final y julio-claudio cuando tengamos edificios de segura cronología y en

${ }^{110}$ H. Rolland, Le Mausolée de Glanum, Paris 1969, p. 26 ss., fig. 4.

111 H. Rolland, L'Arc de Glanum, Paris 1977, fig. 1.

112 J. L. de la Barrera, cit. (n. 15), fig. 13, n' 5

113 J. Puig i Cadafalch, cit. (n. 40), fig. 95.

14 Barrera, cit. (n. 15), p. 384.

115 Lourdes Roldán, Técnicas constructivas romanas en Carteia (San Roque, Cádiz), Madrid 1992, p. 84 ss., fig. 21 A; Barrera, cit. (n. 13), 374, lo fecha en el tercer cuarto del siglo I a. de $\mathrm{C}$.

116 Jorge de Alarcão, «A urbanização de Portugal nas épocas de César e de Augusto» en P. Zanker-W. Trillmich (eds.), Stadtbild und Ideologie, Kolloquium Madrid (1987), München 1990, p. 43 ss., p. 52, lám. 2-h.

117 A. de Franciscis, R. Pane, Mausolei romani in Campania, Napoli 1957, lám. 16 que reproduce un dibujo de Mazois; Valentin Kockel, Die Grabbauten vor dem Herkulaner Tor in Pompeji, Mainz am Rhein 1983, p. 85 ss., lám. 18,a; $21,22$. los que esta cima recta se ve cortada en su mitad por la aparición de un estrecho filete ${ }^{118}$. El análisis de las cornisas de mármol tiene en el material en que se construyen (mármol) y en algunas de sus molduras (sobre todo la cima recta coronando) algunos elementos sobre los que emitir un juicio. A diferencia de la base antes analizada, en las cornisas contamos con piezas similares procedentes del mismo tipo de edificio, el tumular. Desde el punto de vista morfológico, la cornisa destaca por el óvolo y la cima recta que coronan la pieza. Efectivamente, si bien la cima recta es la coronación natural de las cornisas augusteas, la presencia del óvolo remite inmediatamente a un ejemplo galo, la Maison Carrée ${ }^{119}$ con la que mantiene semejanzas en cuanto al desarrollo de alguna de sus molduras. De muy parecidas características a la pieza cordobesa son las cornisas de sendos túmulos; el primero de ellos es el monumento de Lucius Munatius Plancus ${ }^{120}$ datado en la segunda década antes de Cristo; el segundo se localiza en Lucania y coincide con el cordobés en todas sus molduras; se fecha en época de Claudio, si bien se destacan los claros influjos augusteos que presenta ${ }^{121}$. Nos encontramos, de nuevo, con una cronología más cercana al periodo tiberiano que al anterior augusteo, coincidencia ésta que no debe ser juzgada, desde nuestro punto de vista, como debida al azar. Y es en el primero de ellos donde debemos encuadrar la cronología del edificio cordobés.

Para finalizar el estudio de este importante monumento, y a modo de conclusión, intentaremos acercarnos al significado de este edificio en una ciudad como Córdoba. Este tipo de mausoleo circular es afín, como sabemos, al que Augusto construyó en el Campo de Marte para sí y su dinastía ${ }^{122}$; este hecho contribuyó a que las élites locales adoptasen el túmulo como forma de enterramiento, tal y como lo hizo Adriano un siglo después ${ }^{123}$. No es casual que la mayoría de las ciudades italianas contasen con este tipo de enterramiento ${ }^{124}$, por lo que reviste gran

118 Sólo conozco un modelo anterior, similar al cordobés; se trata del templo D de Largo Argentina, fechado en la mitad del siglo I a. de Cristo. Vid. Lucy T. Shoe, Etruscan and republican Roman mouldings. Memoirs of the American Academy in Rome XXVIII 1965, p. 185, lám. LVIII,7.

119 R. Amy, P. Gros, cit. (n. 98), 165 ss.

${ }^{120}$ Rudolf Fellmann, Das Grab des Lucius Munatius Plancus bei Gaeta, Basel 1957, fig. 3, p. 13 ss.

121 V. Bracco, «Studio ricostruttivo di un Mausoleo romano in Lucania», Archeologia Classica XI 1959, p. 189 ss., fig. $5-d$.

${ }_{122} \mathrm{H}$. von Hesberg, S. Panciera, Das Mausoleum des Augustus. Der Bau und seine Inschriften, München 1994.

123 M. Amand, Les tumuli Gallo-Romains, Tongeren 1986, p. 7.

${ }_{124}$ H. von Hesberg, Monumenta. I sepolcri romani e la loro architettura, Milano 1992, 94 ss. 
importancia la aparición de este tipo en Córdoba, alejado físicamente de la región itálica pero cuyos comitentes reivindican, con su elevación, un status particular y una pertenencia a la comunidad romana.

Tema interesante, aunque de difícil confirmación, es el de conocer el comitente de esta obra. La cercanía a una de las puertas de ingreso a la ciudad y la monumentalidad del mismo nos hablan implícitamente de la importancia del personaje; con gran probabilidad pertenecería a la élite local, tal vez al orden ecuestre, por ser éste al que pertenecen los comitentes de obras similares atestiguadas por la epigrafía ${ }^{125}$. Pero también pudo tratarse de un cordobés que hizo carrera (y fortuna) en Italia y que vino a morir a su ciudad natal ${ }^{126}$.

La placa correspondiente a un friso de guirnalda, de época augustea ${ }^{127}$, decorado con guirnaldas, apareció reaprovechada como cubierta de una sepultura. Ignoramos la cronología de la necrópolis del Brillante ${ }^{128}$, zona donde apareció, y tampoco sabemos si esta pieza formó parte de un monumento funerario de la misma necrópolis que fue desmantelado y del que se aprovecharon sus materiales o bien si procede de otra zona de la ciudad. Como parte integrante de un edificio funerario, esta pieza pone de manifiesto un muy cuidado trabajo que concede al monumento al que perteneció un carácter singular en cuanto a dimensiones y ornamento. La tipología de construcciones funerarias hoy conocida permite insertar este fragmento en un túmulo, coronando el tambor cilíndrico ${ }^{129}$, o bien adornaría la fachada de algún otro recinto funerario no necesariamente de planta circular ${ }^{130}$. Para ambos casos resulta destacable su datación en el periodo augusteo medio-tardío.

\subsection{Tholos}

Un fragmento de cornisa en piedra caliza (fig. 34) coronaría este tipo de monumento; sus dentículos podrían indicar un momento reciente del siglo I de C. para su edificación.

125 F. van Wonterghen, «Monumento funerario di un tribunus ilitium a Corfinio», Acta Archaeologica Lovainiensia 21, 1982, p. 120.

126 Vid. el caso parecido de M. Calpurnius Rufus, legado de Claudio, en W. Eck, ZPE 86, 1991, p. 97 ss., 101 Amm 22. Agradezco a M. Schwartz esta información.

127 C. Márquez en D. Vaquerizo (ed.), Catálogo de la Exposición Córdoba en tiempos de Séneca, Córdoba 1996, 212.

${ }_{128}$ A. M. Vicent, AEspA 45-47, 1972-1974, 113 ss.

129 Como el notorio ejemplo de la tumba de Cecilia Metela en la Vía Apia. Vid. Hesberg, cit. (n. 124), 116, fig. 137.

130 Véase el ejemplo del Mausoleo de los Atilii en Sádaba en J. Menéndez Pidal, «El Mausoleo de los Atilios», AEspA 43,1970 , p. 89 ss.

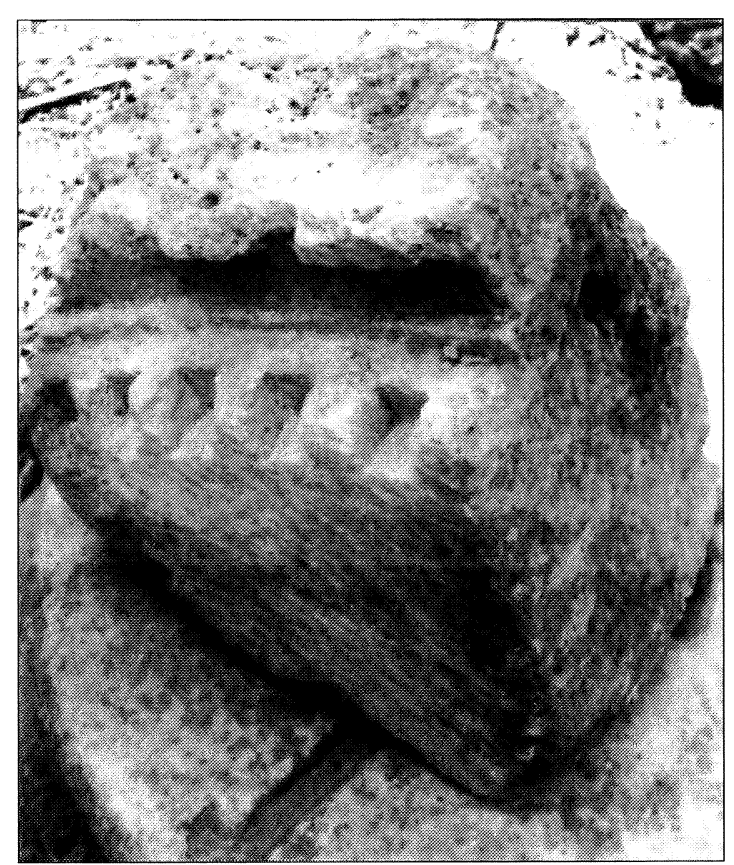

Fig. 34.-Cornisa de una tholos funeraria.

\subsection{Edícolas}

Se trata de un tipo muy extendido por todo el imperio y que tiene en la necrópolis de Sarsina sus mejores y más conocidos ejemplos. También en este caso existe una amplia y variada tipología ${ }^{131}$ aunque contaban siempre con dos elementos: el zócalo y la edícola en la que, generalmente, se colocaba la imagen del propietario de la tumba. La rica y variada gama compositiva en la propia estructura del monumento se multiplicaba con los adornos a él añadidos; entre los ejemplos cordobeses podemos añadir algunos frisos, fechados en un periodo julio-claudio (fig. 35).

\subsection{Recintos funerarios}

En la zona conocida como Campo de la Verdad, al otro lado del río Guadalquivir, aparecieron dos relieves (figs. 36-37) ${ }^{132}$ con una muy peculiar decoración a base de personajes alados cuya mitad inferior está formada por unos motivos acantiformes y que sostienen en sus manos unos tallos que conclu-

\footnotetext{
131 Hesberg, cit. (n. 122), 144 ss.

132 Su adscripción a un monumento funerario está fuera de toda duda leyendo las anotaciones de D. Samuel de los Santos en el Libro-Registro del Museo Arqueológico, donde indica que «era un costado del recinto».
} 


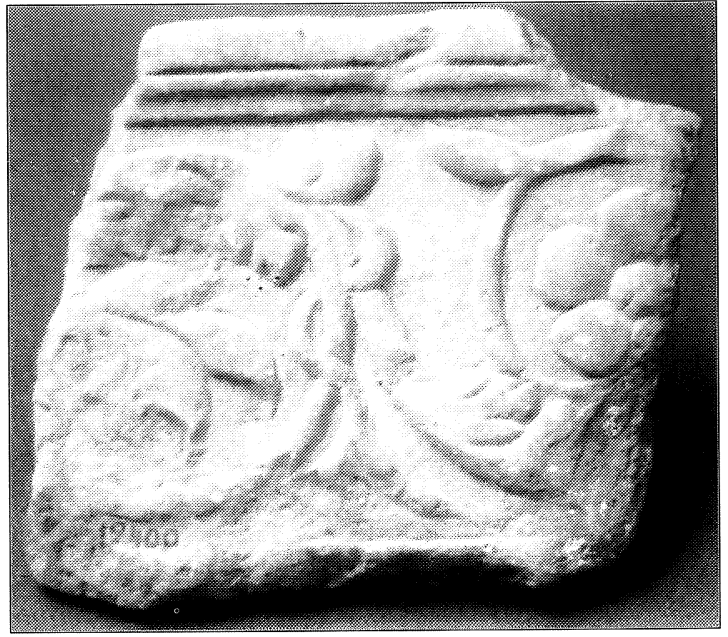

Fig. 35.-Friso de probable adscripción funeraria.

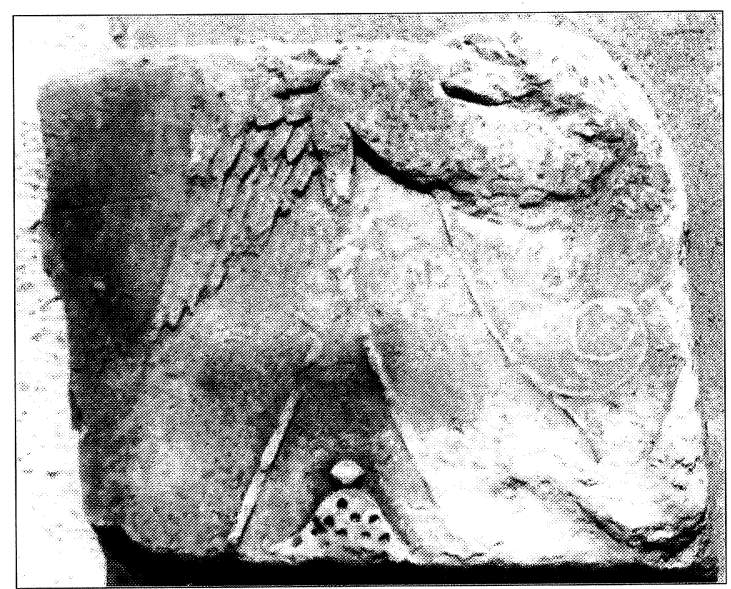

Fig. 36.-Relieve funerario

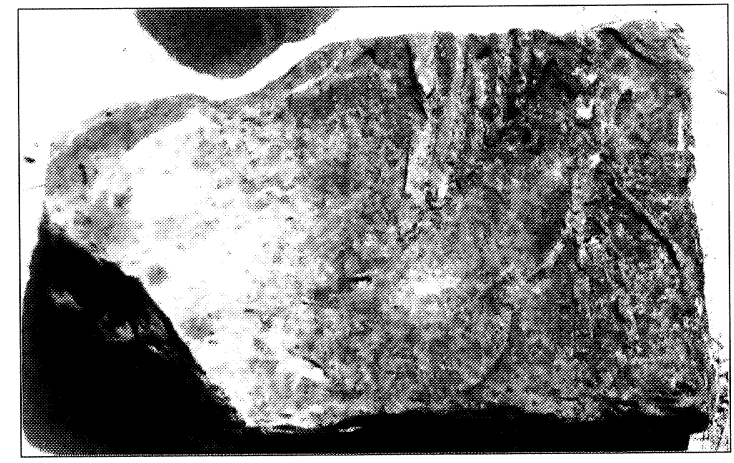

Fig. 37.-Relieve funerario. yen en unas guirnaldas. La vegetalización, exagerada, que se ha dado a las figuras aladas puede aproximar la cronología de estas piezas al periodo flavio ${ }^{133}$, si bien este particular tipo femenino cuenta con orígenes helenísticos y será en el periodo augusteo cuando adopte un particular significado ideológico vinculado con el complejo proyecto augusteo de propaganda ${ }^{134}$.

En espera de que próximas intervenciones arqueológicas obliguen a modificar o a matizar las ideas aquí vertidas, éste es por el momento el estado actual de la cuestión.

\section{Addendum}

Corregidas las primeras pruebas de imprenta, han aparecido en el número 5 de la calle Morería los restos de un podium y un fragmento de fuste, cuyo diámetro es superior a $140 \mathrm{~cm}$, además de multitud de elementos arquitectónicos, cuyas dimensiones van en consonancia con las medidas que en este trabajo hemos establecido. Esta información, que confirma la existencia del templo colosal, nos ha sido facilitada generosamente por D. ${ }^{a}$ Inmaculada Carrasco y D. Ricardo García, directores de la excavación arqueológica.

133 Blanckenhagen, Flavische Architekturtor und ihre Dekoration, Berlin (1940) p. 65 , figs. 54, 57; p. 66, figs. 65,66 y 67.

134 A. Giuliano (ed.), La collezione Boncompagni Ludovisi. Algardi, Bernini e la fortuna dell'antico, Venezia 1992, 142 ss. 